\title{
EL INCUMPLIMIENTO Y LOS REMEDIOS DEL ACREEDOR EN LA PROPUESTA DE MODERNIZACIÓN DEL DERECHO DE LAS OBLIGACIONES Y CONTRATOS ESPANOL
}

BREACH OF CONTRACT AND REMEDIES FOR THE CREDITOR IN THE PROPOSED MODERNIZATION OF SPANISH OBLIGATION AND CONTRACT LAW

\section{O INCUMPRIMENTO E OS REMÉDIOS DO CREDOR NA PROPOSTA DE MODERNIZAÇÃO DO DIREITO DAS OBRIGAÇÕES E CONTRATOS ESPANHOL}

Álvaro Vidal Olivares*

\section{RESUMEN}

El presente artículo analiza el régimen de incumplimiento y sus efectos en la propuesta de modernización del Derecho de Obligaciones y contratos español, considerando tanto la propia propuesta de reforma como también lo que se estima son las ideas claves para la construcción de un nuevo orden sobre el incumplimiento contractual, acorde con las actuales condiciones del tráfico y funcional al interés del acreedor. Tales ideas son: la comprensión del contrato, la noción de incumplimiento, la pluralidad de remedios

* Este artículo forma parte del proyecto FONDECYT regular $\mathrm{N}^{\circ} 1100284$ "Por una reforma a las reglas de incumplimiento contractual en el Código Civil”.

** Profesor de la Pontificia Universidad Católica de Valparaíso, Valparaíso, Chile, doctor en Derecho por la Universidad Autónoma de Madrid. Dirección postal: Facultad de Derecho, Pontificia Universidad Católica de Valparaíso, avenida Brasil 2950, Valparaíso, Chile. Artículo recibido el 29 de diciembre de 2010 y aceptado para su publicación el 30 de mayo de 2011. Correo electrónico: alvaro.vidal@ucv.cl 
y la opción del acreedor. Se busca su identificación dentro de la reforma proyectada, considerando los modelos de Derecho Contractual europeo e internacional que la propuesta sigue en su afán de armonización.

Palabras clave: modernización, obligaciones, incumplimiento, remedios.

\section{AbSTRACT}

This paper analyzes the system applicable to default and its effects in the context of a proposal to modernize the law of obligations and contracts in Spain. The paper addresses both the proposed reform and what appear to be key ideas for the construction of a new order on breach of contract, based on current usage and functionality for the creditor. Such ideas include: understanding the contract, notion of default, plurality of remedies and the option of the creditor. The paper seeks to identify these ideas within the planned harmonization effort in light of European and international contract law models.

Key words: modernization, obligations, default, remedies.

RESUmo

$\mathrm{O}$ presente artigo analisa o regime de incumprimento e seus efeitos na proposta de modernização do direito de obrigações e contratos espanhol, considerando tanto a própria proposta de reforma, como também o que se estima são as idéias chaves para a construção de uma nova ordem sobre o incumprimento contratual, de acordo com as atuais condições do tráfico e funcional ao interesse do credor. Tais idéias são: a compreensão do contrato, a noção do incumprimento, a pluralidade de remédios e a opção do credor. Busca-se a sua identificação dentro da reforma projetada, considerando os modelos de direito contratual europeu e internacional que a proposta segue em seu afã de harmonização.

Palavras chaves: modernização, obrigações, incumprimento, remédios.

\section{INTRODUCCIÓN}

El presente trabajo tiene por finalidad el análisis del régimen del incumplimiento contractual y sus efectos en la Propuesta de Modernización del Código 
Civil. Tal estudio lo haré a partir de lo que entiendo son las ideas claves para la construcción de un sistema de incumplimiento, funcional al interés del acreedor y adecuado a las actuales condiciones del tráfico; a saber:

(1) la comprensión del contrato,

(2) la noción del incumplimiento

(3) y la pluralidad de remedios y la opción del acreedor ${ }^{1}$. Se quiere verificar en qué medida ellas están presentes en la propuesta elaborada por la Comisión de Codificación. Al mismo tiempo, cuando proceda, se comparará el régimen sugerido con las soluciones de aquellas ordenaciones que sirvieron de modelo a la Comisión de Codificación, esto es, la Convención de Viena, los Principios UNIDROIT ${ }^{2}$ y los PECL $^{3,4}$.

¿Por qué podría interesar el examen de una propuesta de modificación al Código Civil español? Hoy puede apreciarse en algunos ordenamientos jurídicos, una tendencia más o menos intensa hacia la modernización y armonización del 2 decimonónico de las obligaciones y de su incumplimiento, cuyo texto codificado actualmente se considera inadecuado para dar

${ }^{1}$ Ideas claves propuestas y desarrolladas para una relectura de las normas del Código Civilsobre incumplimiento contractual en Álvaro VIDAL OLIVARES, "El cambio de paradigma en el incumplimiento contractual", en Patricio Carvajal Ramírez (coord.), Estudios en Homenaje el Profesor Alejandro Guzmán Brito (en prensa). También Álvaro Vidal Olivares, "La noción de incumplimiento esencial en el Código Civil", en Revista de Derecho PUCV, vol. XXXII, N $1^{\circ}$, Valparaíso, 2009, pp. 226-237. Se advierte que he propuesto como cuarta idea clave la razonable gestión de los remedios por parte del acreedor. Sin embargo, no la he incorporado en este trabajo, debido a que su presencia se aprecia con ocasión del examen del régimen de cada remedio en particular. Para un estudio de la gestión razonable en el derecho contractual, véase Álvaro Vidal Olivares, "La gestión razonable de los efectos del incumplimiento en la compraventa internacional”, en Revista de Derecho de la Universidad Austral de Chile, vol. 18, № 1, Valdivia, 2005.

${ }^{2}$ UNIDROIT, Instituto Internacional para la Unificación del Derecho Privado, Principios UNIDROIT sobre los contratos comerciales internacionales, Roma, Ediciones UNIDROIT, 2004. Versión española dirigida por Alejandro A.M. Garro, Madrid, Ediciones UNIDROIT, 2007.

${ }^{3}$ The Commission on European Contract Law, Ole Lando, Hugh Beale (eds.), Principles of European Contract Law, The Hague, Kluwer Law International, 2000, Parts I and ir y Luis Díez-Picazo, Encarna Roca Trias y Antonio Manuel Morales Moreno, Los Principios del Derecho Europeo de Contratos, Madrid, Civitas, 2002.

${ }^{4}$ No se considera el DCFR porque es posterior a la Propuesta de modernización y, por consiguiente, la sección civil de la Comisión de Codificación no lo pudo tener a la vista al elaborar la propuesta. Como sea, el DCFR en materia de incumplimiento recoge soluciones muy similares a las de los PECL. Véase Study Group on a European Civil Code and Research Group on EC Private Law (Acquis Group), edited by Christian von Bar, Eric Clive and Hans Schulte -Nölke and Hugh Beale, Johnny Herre, Jérome Huet, Peter Schlechtriem, Matthias Storme, Stephen Swann, Paul Varul, Anna Veneziano and Fryderyk Zoll, Principles, Definitions and Model Rules of European Private Law, Draft Common Reference (DCFR) Interim Outiline, Munich, European Law Publishers, 2008. 
solución a los problemas de incumplimiento, atendiendo a las actuales condiciones del tráfico ${ }^{5}$. En estos ordenamientos, la ley civil sobre la materia es similar y en algunos tópicos idéntica, al tener como antecedente inmediato el Código Civil francés. De esta manera, la referida tendencia modernizadora reconoce distintas etapas, sin hacerse esperar una reforma legal.

Así, en una primera fase se observan importantes esfuerzos por reinterpretar las normas sobre el incumplimiento y sus efectos, atendiendo los cambios que desde el siglo XIX ha experimentado la actividad contractual, siguiendo muy de cerca la disciplina del incumplimiento y los principios en que ella se basa de la Convención de Viena, los Principios de UNIDROIT y los PECL ${ }^{6}$. Por su parte, en una segunda etapa se hallan ordenamientos como el español ${ }^{7}$, en los que al esfuerzo doctrinal con acogida jurispru-

${ }^{5}$ Álvaro Vidal Olivares, "El incumplimiento de las obligaciones con objeto fungible y los remedios del acreedor afectado. Una relectura de las disposiciones del Código Civil sobre incumplimiento", en Alejandro GuZmán Brito (ed.), El Código Civil de Chile (18552005), Santiago, LexisNexis 2007, p. 495 y ss.

${ }^{6}$ En esta tarea de relectura de las normas del Código Civil con el objetivo de adaptarlas a las actuales condiciones del tráfico y armonizar nuestro Derecho de Obligaciones a las nuevas tendencias europeas e internacionales, entre otros y con algunos de sus trabajos: Enrique BARROS BourIE, "Finalidad y alcances de las acciones y los remedios contractuales", en Alejandro 246 GuZmán Brito (ed.), Estudios de Derecho Civil III, Santiago, Legal Publishing, 2008; Enrique Barros BOURIE, "La diferencia entre 'estar obligado' y 'ser responsable' en el derecho de los contratos", en Hernán Corral, María Sara Rodríguez (eds.), Estudios de Derecho Civil II, Santiago, Lexis Nexis, 2006; María Graciela BrantT Zumarán, "Exoneración de responsabilidad y extinción de la obligación: delimitación de las nociones de caso fortuito e imposibilidad sobrevenida de la prestación”, en Alejandro GuZMán Brito (ed.), Estudios de Derecho Civil III, Santiago, Legal Publishing, 2008, pp. 479-502; María Graciela BrantT Zumarán, El caso fortuito y su incidencia en el derecho de la responsabilidad civil contractual. Concepto y función del caso fortuito en el Código Civil chileno, Santiago, Legal Publishing, 2010; Iñigo DE LA MAZA GAZMurI, "A propósito del artículo 1861 del Código Civil”, en Departamento de Derecho Privado de la Universidad de Concepción (coord.), Estudios de Derecho Civil v, Santiago, Legal Publishing, 2010, pp. 455-470; Claudia MejÍAS Alonzo, "El incumplimiento contractual y sus modalidades", en Alejandro GuZMán BRito (ed.), Estudios de Derecho Civil III, Santiago, Legal Publishing, 2008, pp. 459-478; Carlos PIZARro WILSON, "La culpa como elemento constitutivo del incumplimiento en las obligaciones de medio o de diligencia", en Revista de Derecho PUCV, vol. xxxi, N 1, Valparaíso, 2008; Carlos Pizarro Wilson, "Hacia un sistema de remedios al incumplimiento contractual", en Alejandro GuZMán Brito (ed.), Estudios de Derecho Civil III, Santiago, Legal Publishing, 2008. Vidal Olivares, "El cambio de paradigma..." (n. 1); Vidal Olivares, "La noción de incumplimiento..." (n. 1), pp. 226-237; Álvaro VIDAL Olivares, "La pretensión de cumplimiento específico y su inserción en el sistema de remedios por incumplimiento en el Código Civil”, en Hernán CorRaL, María Sara Rodríguez (eds.), Estudios de Derecho Civil II, Santiago, Lexis Nexis, 2006, p. 527; Álvaro Vidal Olivares, La protección del comprador: régimen de la Convención de Viena y su contraste con el Código Civil, Valparaíso, Ediciones Universitarias de Valparaíso, 2006, p. 187; Vidal Olivares, "El incumplimiento de las obligaciones..." (n. 5), pp. 525-527.

${ }^{7}$ También, aunque con una marcada resistencia, es el caso del Derecho Civil francés. En Francia hoy circulan tres anteproyectos de reforma al Code Civil, uno que se resiste a lo foráneo y 
dencial hoy se suman propuestas de transformación de la legislación de las obligaciones y contratos, las que pese a introducir reformas profundas, respetan la tradicional estructura de su Código Civil $^{8}$.

Esta tarea modernizadora se entiende concluida al materializarse una modificación legal que ofrezca soluciones funcionales, acorde con las actuales condiciones del tráfico, armonizando la normativa interna con la de los ordenamientos del entorno y aquéllos representativos del Derecho uniforme de la contratación, transnacional e internacional ${ }^{9}$.

otros dos, abiertos a la influencia del Derecho Contractual europeo, encabezado por los PECL. (1) Pierre Catala, Avant-projet de réforme du droit des obligations et de la prescription. La documentation française, Paris, Ministère de la Justicie, 2006 (en adelante "Proyecto Catala"); (2) Proyecto de Reforma del derecho de los contratos, denominado de la Chancellerie y (3) el Proyecto de reforma del profesor François Terré; estos dos últimos del año 2008. Para Denis Mazeaud, el Proyecto Catala representa la resistencia a lo foráneo y constituye una especie de maquillaje al Code Civil, que permite verle más joven, pero sin cuestionar su estructura o las instituciones que lo integran. En cambio, los otros dos proyectos representan la apertura al Derecho Común europeo de los contratos al punto de que llegan a romper el modelo francés. Denis MAZEAUD, "La reformé du droit français des contrats: trois projets en concurrence", dans Blandine MALLET-BRICOUT et Sarah Bros, Liber Amicorum Christian Larroumet, Paris, Économica, 2009, p. 256 y ss. Por su parte, Antonio Cabanillas Sanchéz, comentando el Proyecto Catala, explica que pese a que su autor en la presentación general del anteproyecto, afirmó que estaba en la voluntad del legislador atender a las necesidades del tiempo presente, el resultado diverge en gran medida de los Principios de Derecho Contractual Europeo de la Comisión Lando, de los Principios UNIDROIT, o de la Convención de Viena de 1980. Antonio Cabanillas Sanchéz, "El Anteproyecto francés de reforma del Derecho de obligaciones y del Derecho de la prescripción (Estudio preliminar y traducción)", en Anuario de Derecho Civil, fascículo II, Madrid, 2007, p. 624. Para un detenido estudio comparativo del régimen del incumplimiento en los tres proyectos franceses véase Carlos PizArRo Wilson, "Una mirada a los remedios al incumplimiento contractual en los proyectos de reforma en Francia”, en Revista de Derecho PUCV, vol. ?, No 1, 2011 (en prensa).

${ }^{8}$ Así lo reconoce Nieves Fenoy al expresar: "Es conocido que en España, de un tiempo para acá y a nivel doctrinal, se está llevando a cabo una reflexión y una progresiva renovación del Derecho de las obligaciones contractuales (Luis Díez-Picazo, Pantaleón Morales Moreno, etc.). Dentro de este sector del Derecho, especial atención ha merecido el incumplimiento del contrato y sus remedios. Nuestro Código Civil puede aplicarse desde una visión tradicional o desde otra modernizadora (a través de los criterios interpretativos de las normas del art. $3.1 \mathrm{del} C C$ ). La interpretación modernizadora es un anterior paso que puede permitir abrir camino a una efectiva reforma del Derecho. Las propuestas mercantil y civil constituyen el siguiente paso cualitativo del proceso legislativo español de la modernización de las obligaciones contractuales, si éste llega a culminarse". Nieves FENOY Picón, "La modernización del régimen del incumplimiento del contrato: Propuestas de la Comisión General de Codificación. Parte Primera: Aspectos generales. El incumplimiento”, en Anuario de Derecho Civil, fascículo I, tomo LXIII, Madrid, 2010, p. 51.

${ }^{9}$ Es el caso alemán que el año 2002 modifica su $B G B$, modernizando su Derecho de Obligaciones. Reinhard Zimmermann, El nuevo Derecho alemán de obligaciones. Un análisis desde la historia y el Derecho Comparado, traducción de Esther Arroyo i Amayuelas, Barcelona, Bosch, 2008; Martín EBErs, "La nueva regulación del incumplimiento contractual en el BGB, tras la Ley de modernización del Derecho de obligaciones de 2002", en Anuario de Derecho Civil, fascículo Iv, volumen LVI, Madrid, 2003, p. 1.565 y ss. 
No se pretende importar a nuestro ordenamiento regulaciones foráneas de carácter transnacional e internacional, sino que se persigue ver en ellas un modelo y, a partir de la concreta realidad de nuestro tráfico, desplegar esfuerzos doctrinales y jurisprudenciales que al interpretar y aplicar la disciplina de incumplimiento consideren esta realidad, dando una lectura distinta a sus disposiciones a objeto de proporcionar soluciones adecuadas. La experiencia europea e internacional constituye una mera orientación y, en caso alguno, implica un compromiso, menos una atadura.

En consecuencia, interesa conocer y analizar la propuesta de modernización española, con el fin de apreciar cómo y en qué medida un ordenamiento perteneciente a la familia del Derecho Civil continental, respetando la tradición y estructura del Código Civil, avanza, ahora mediante la propuesta de una reforma legislativa, en la renovación y armonización del Derecho de Obligaciones y contratos, en particular, en lo que concierne al incumplimiento de éstos y sus efectos.

La dispersa y deficiente regulación de esta materia contenida en el Código Civil español y, más aún, su lectura tradicional, al igual que en el caso chileno, hoy resultan obsoletas y son objeto de importantes críticas, siendo éstas, junto con el influjo del Derecho Contractual europeo y uniforme de los contratos, el impulso de un importante trabajo doctrinario y jurisprudencial, que desemboca en propuestas concretas de modificación legal.

$\mathrm{El}$ presente trabajo se divide en dos secciones y termina con un cuerpo de conclusiones. La primera refiere a la Propuesta de Anteproyecto de modificación del Código Civil, a sus motivos, fuentes y estructura; y la segunda, tiene por objetivo el estudio del régimen del incumplimiento de la propuesta a la luz de las ideas claves ya mencionadas.

\section{SeCCIÓN I}

La PROPuesta de MOdernizaCión del Código CIVIL EN MATERIA DE DERECHO DE OBLIGACIONES Y CONTRATO

La necesidad de modernización del Derecho español de las obligaciones y contratos surge tempranamente tras la entrada en vigencia en España de la Convención de Viena. El profesor Luis Díez-Picazo afirma que en la reconstrucción del Derecho de Obligaciones,

"un momento culminante fue sin duda el Convenio de Viena sobre Venta Internacional de Mercaderías -y agrega-. Entre mis recuerdos guardo la impresión que me produjo la lectura casual del Convenio en el Boletín Oficial del Estado y la inmediata idea de que había que dedicarse a estudiarlo". 
Y al referirse a la modernización del Derecho de Obligaciones afirma que el problema de esta parcela del Derecho Civil no es sólo de aspecto:

"hay problemas de interna coherencia del conjunto normativo, que, sin alterar los designios políticos que en él puedan existir, permitan entenderlo mejor y aplicarlo más adecuadamente -y sigue- es casi seguro que el estado actual de nuestro Derecho de obligaciones aconseja alguna reforma que lo ponga en consonancia con los últimos textos europeos".

Finaliza diciendo:

"en cualquier caso, hay que decir que, en espera de la reforma o sin ella, corresponde a los estudiosos y a los profesores esa búsqueda de la interna coherencia que el conjunto correctamente entendido debe tener" ${ }^{\prime \prime}$.

Este esfuerzo por dotar de coherencia interna al Derecho de Obligaciones queda reflejado en la propia obra del profesor Luis Díez-Picazo, quien recientemente ha publicado la sexta edición de su libro Fundamentos de Derecho Civil Patrimonial II. Las relaciones obligatorias, que recoge una interpretación de las disposiciones del Código Civilsobre la materia, armonizada con los textos europeos e internacionales de Derecho de los Contratos ${ }^{11}$.

Destacan, además, por sus aportaciones a la tarea de reconstrucción del Derecho de Obligaciones español, los profesores Fernando Pantaleón

${ }^{10}$ Luis Diez-Picazo, "Prólogo", en Antonio Manuel Morales Moreno, La modernización del derecho de las obligaciones, Madrid, Civitas, 2006. Luis Diez-PicAzo, reconociendo que es España es un país abierto a la influencia externa, en particular del derecho alemán y uniforme sobre compraventa internacional de mercaderías, "Reforma de los Códigos y derecho europeo", en Anuario de Derecho Civil, fascículo Iv, volumen LVI, Madrid, 2003, p. 1.565 y ss.

${ }^{11}$ Antonio Manuel Morales Moreno, destacando la tarea de Luis Díez-Picazo en el proceso de la modernización del Derecho de Obligaciones expresa: "Es, asimismo, de singular valor, la labor de modernización que ha desarrollado y continúa desarrollando el Prof. Luis Díez-Picazo, tanto en sus Fundamentos del Derecho Patrimonial Civil como en otras publicaciones. El empeño de Luis Díez-Picazo en la modernización del Derecho de obligaciones español traspasa el plano doctrinal. Como Presidente de la Sección Civil de la Comisión General de Codificación, ha impulsado los trabajos preparatorios de modernización del libro IV del Código civil español, dedicado a las 'obligaciones y contratos', en sus títulos primero ('De las obligaciones') y segundo ('De los contratos'); y, asimismo, otros trabajos orientados a la modificación del régimen de algunos contratos en el CC, como el de compraventa", Antonio Manuel Morales Moreno, "Evolución del concepto de obligación en Derecho español”, en Antonio Manuel Morales Moreno, La Modernización del Derecho de Obligaciones, Navarra, Thomson-Civitas, Cizur Menor, 2006, p. 29. 
Prieto $^{12}$ que el año 1993 publica "Las nuevas bases de la responsabilidad civil contractual" ${ }^{13}$ y el profesor Antonio Manuel Morales Moreno con su obra La modernización del derecho de las obligaciones, que reúne una serie de trabajos desperdigados sobre la materia ${ }^{14}$ y quien luego, en el año 2010, publica Incumplimiento del contrato y lucro cesante ${ }^{15}$. He querido destacar la participación de estos tres juristas españoles por lo gravitante de su papel en la tarea modernizadora, sin ánimo de excluir a otros que, desde luego, han contribuido, y lo seguirán haciendo, en el proceso modernizador ${ }^{16}$.

\section{Las propuestas de reforma legal de la Comisión de Codificación de España $a^{17}$}

La Comisión de Codificación de España ha elaborado tres propuestas de modernización del Derecho de Obligaciones y Contratos. Dos de ellas se

${ }^{12}$ Antonio Manuel Morales Moreno, también, se refiere a la influencia de Pantaleón Prieto en el proceso de modernización del derecho de obligaciones al afirmar: "Tuvo una gran importancia, en este sentido (en la tendencia orientada hacia la modernización del derecho de obligaciones), el trabajo que Fernando Pantaleón publicó en el Anuario de Derecho Civil, el año 1993 [fascículo cuarto], bajo el título: 'Las nuevas bases de la responsabilidad contractual'. En él diseña, de modo certero, las líneas maestras conforme a las cuales debe procederse a revisar el derecho de obligaciones español”. Op. cit., p. 28.

${ }^{13}$ Fernando Pantaleón Prieto, "Las nuevas bases de la responsabilidad contractual", en Anuario de Derecho Civil, fascículo Iv, volumen 46, Madrid, 1993, pp.1719-1745. Antes Fernando Pantaleón PRieto, "El sistema de responsabilidad contractual (materiales para un debate)", en Anuario de Derecho Civil, fascículo III, volumen 44, Madrid, 991, pp. 1.0191.091 .

${ }^{14}$ Destaca el trabajo titulado "Evolución del concepto de obligación en el derecho español”, que sienta las bases para la modernización del Derecho de Obligaciones desde que antes de dar una mirada a los modelos de Derecho europeo y uniforme, se detiene en los problemas referidos al incumplimiento contractual en el tráfico interno español y a la evolución doctrinal y jurisprudencial sobre la materia. Morales Moreno (n. 11), pp. 17-54.

${ }^{15}$ Antonio Manuel Morales Moreno, Incumplimiento del contrato y lucro cesante, Navarra, Thomson Civitas, 2010.

${ }^{16}$ Así, se destacan los trabajos de Nieves Fenoy Picón, El sistema de protección del comprador, Madrid, Tirant lo Blanch, 2006 y Nieves Fenoy Picón, La falta de conformidad e incumplimiento en la compraventa (Evolución del ordenamiento español), Madrid, Centro de Estudios Registrales, 1996 y los de Lis Paula San Miguel Pradera, La resolución del contrato por incumplimiento y sus modalidades de ejercicio, Madrid, Colegio de Registradores de la Propiedad y Mercantiles de España, 2004.

${ }^{17}$ Acerca de las características y cualidades de las propuestas de la modernización, véase Carmen Jerez Delgado y Máximo Juan Pérez García, "La Comisión General de Codificación y su labor en la Modernización del Derecho de Obligaciones", en RJUAM, No 19, Madrid, pp. 155-179, p. 166: "Estas propuestas, que la Comisión General de Codificación eleva al Ministerio de Justicia en su calidad de órgano asesor, tienen en común su carácter científico, independiente y no vinculante, así como el constituir un referente para la reflexión jurídica”. 
redactaron por la sección civil, que propone la modificación del Código Civil en materia de obligaciones y contratos en general (en adelante la Propuesta de modernización del Código Civil) y de la compraventa (en adelante la Propuesta de compraventa); la tercera, se preparó por la sección mercantil, que hace lo suyo para los contratos mercantiles (en adelante la Propuesta Mercantil $)^{18}$. En este trabajo me ocuparé del análisis de la Propuesta de modernización del Código Civil, sin perjuicio de las referencias que haga, cuando así sea necesario, a las restantes.

Formalmente, existen dos ediciones de la Propuesta de modernización del Código Civil; una inicial, que refiere a la parte general de obligaciones y contratos, a la que le sucede una segunda versión con alcance más extendido.

El primer texto señalado, publicado por la Comisión General de Codificación en el Boletín de Información del Ministerio de Justicia, del mes de enero de 2009, se titula "Propuesta de modernización del Código Civil en materia de Obligaciones y Contratos" y precisa en su interior que es una propuesta de anteproyecto de modificación del Código Civil. La segunda iniciativa, publicada el mismo año por el Ministerio de Justicia, se titula "Propuesta para la modernización del derecho de obligaciones y contratos" y fusiona la primera edición con la Propuesta de compraventa, que fuera publicada con anterioridad por el Ministerio de Justicia en el Boletín de Información del mes de mayo de 2005. En esta segunda edición, se añaden en la Exposición de motivos aquéllos previstos en la Propuesta del contrato de compraventa y, enseguida, los respectivos artículos que se modifican ${ }^{19}$. En este trabajo se hará mención separadamente a los motivos y artículos de las propuestas de modernización del Código Civil y a la Propuesta de compraventa.

${ }^{18}$ Ministerio de Justicia, "Propuesta de Anteproyecto de Ley de Modificación del Código de Comercio, Parte General sobre Contratos mercantiles y sobre prescripción y caducidad", en Boletín de Información, año LXI, No 2006, Madrid, febrero de 2006, pp. 605-618. La propuesta elaborada por la sección mercantil de la Comisión General de Codificación, modifica el artículo $1^{\circ}$ del Código de Comercio (artículo primero), los artículos 50 a 63, disposiciones que junto con los nuevos artículos 64 a 80, forman el título IV "Disposiciones generales sobre los contratos mercantiles".

${ }^{19}$ Nieves Fenoy afirma: "Es perceptible la continuidad sistemática que media entre ambas Propuestas civil y sobre compraventa" y agrega que ello lo confirma el hecho de que el Ministerio de Justicia, después de haber publicado la "Propuesta sobre compraventa" y la "Propuesta civil" en su Boletín de Información, haya publicado en 2009 un pequeño libro en el que ambas aparecen unidas como una única, bajo el título de Propuesta para la modernización del Derecho de obligaciones y contratos de la Comisión General de Codificación. El libro se aportó a unas jornadas que celebró el Ministerio de Justicia en febrero de 2010 para presentar esta proposición de la Comisión General de Codificación. 


\section{La Propuesta de modernización del Código civil Estructura y motivos}

La Propuesta de modernización del Código Civil es obra, como se ha anunciado, de la sección primera de Derecho Civil de la Comisión General de Codificación del Ministerio de Justicia de España y contiene una relación de los integrantes que participaron en su elaboración, en reuniones celebradas entre el 23 de noviembre de 1994 y el 28 de mayo de 2008, todas presididas por el profesor Luis Díez-Picazo ${ }^{20}$. Debe observarse que se echa en falta la participación de algunos civilistas destacados en el medio español, como Manuel Albaladejo, Rodrigo Bercovitz y Pablo Salvador Coderch, entre otros; sin embargo, no quiere decir que quienes no integraron la sección primera no intervendrán en el proceso que conduzca a la materialización de la modificación del Código Civil. La Propuesta de modernización es un punto de partida y precisamente, es la academia la llamada a hacer sus aportaciones a través de estudios y comentarios críticos de la pretendida reforma ${ }^{21}$.

La propuesta es fiel a la estructura básica del Código Civil. En efecto, conserva los títulos I "De las obligaciones" y II "De los contratos", dentro del libro IV, introduciendo modificaciones esenciales a su contenido y

${ }^{20}$ José Luis Álvarez Álvarez, Manuel Amorós Guardiola, Ricardo de Ángel Yaguez, Alberto Ballarín Marcial, D. Roberto Blanquer Uberos, D.a Alegría Borrás Rodríguez, Jorge Caffarena Laporta, Alfonso Calvo Caravaca, Eduardo Cerrós Sánchez Herrera, José María Chico Ortiz, Jesús Díez Del Corral y Rivas, José Antonio Escartín Ipiens, Diego Espín Cánovas, José Ferrandis Vilella, Manuel Gitrama González, Francisco Javier Gómez Gálligo, Julio Diego González Campos, Carmen de Grado Sanz, Carlos Lasarte Álvarez, Ramón López Vilas, Mariano Martín-Granizo Fernández, Luis Martínez- Calcerrada y Gómez, Francisco Mata Pallares, José María Miquel Gonzalez, José Miura Fuentes, Vicente Montes Penadés, Antonio Manuel Morales Moreno, José Luis de los Mozos y de los Mozos, Francisco Núñez Lagos, Fernando Pantaleón Prieto, Antonio Pau Pedrón, Manuel Peña y Bernaldo de Quirós, José Poveda Díaz, Encarna Roca i Trías, Antonio Rodríguez Adrados, Manuel Ángel Rueda Pérez, Luis Sancho Mendizábal, Juan Sarmientos Ramos, María Concepción Sierra Ordóñez, Manuel Taboada Roca, María Telo Núñez, Miguel Virgos Soriano, vocal de la Sección Segunda de Derecho Mercantil. Anexo de la "Propuesta de Modificación al Código Civil".

${ }^{21}$ Nieves Fenoy, pronunciándose sobre la importancia de la discusión de las propuestas de reforma, afirma: "El progresivo análisis que los autores vayamos haciendo de las Propuestas de reforma de la Comisión General de Codificación, contribuirá a su difusión, entendimiento y perfeccionamiento (indicando si es o no norma oportuna, si proceden ciertos cambios, etc.) y, si se es partidario de la reforma, tal vez pueda lograrse el convencimiento de una mayoría suficiente de juristas y políticos. Otra cosa es la oportunidad, pero esto depende de los agentes políticos. Ahora bien, llamar su atención sobre la necesidad de reforma es algo que, entiendo, no puede soslayarse, si se persigue la consecución de tal objetivo”. FENOY PICÓN (n. 8), p. 130. 
ordenación, especialmente en materia de inejecución ${ }^{22}$. El capítulo VII del título I del libro IV regula el incumplimiento y sus remedios (artículos 1188 a 1212). Y la sección primera del mencionado capítulo contiene las "Disposiciones generales", que definen el incumplimiento (artículo 1188) y los distintos remedios de que dispone el acreedor (artículos 1190 y 1191). Las secciones posteriores reglamentan en particular los remedios -acción de cumplimiento (artículos 1192 a 1196), reducción del precio (artículos 1197 y 1198), resolución (artículos 1199 a 1204) e indemnización de daños (artículos 1205 a 1212) - fijando las condiciones, límites de aplicación y efectos de cada uno de ellos ${ }^{23}$.

La propuesta opta por lo que se ha llamado una concepción unitaria y articulada del incumplimiento, constitutivo del presupuesto jurídico de un conjunto de remedios del acreedor, no obstante que cada uno posee sus propias condiciones de aplicación. Como afirma Nieves Fenoy

"una de las claves del posible éxito de esta estructura conceptual (la del capítulo viI) es que se trata de una idea simple y sencilla -agregando que ella- cumple bien la función de organizar al incumplimiento"

y considera adecuada su adopción en la Propuesta de modernización ${ }^{24}$.

(1) En la Exposición de motivos del texto en estudio, aparecen las razones que explican la modificación al Código Civil español en materia de obligaciones y contratos y la finalidad que ella persigue;

(2) los principios y rasgos característicos del régimen del incumplimiento y de los remedios del acreedor.

(1) En lo que refiere a lo primero, la Exposición de motivos comienza expresando que, en la actualidad, hay muy pocas personas que discutirían la conveniencia de reformar los preceptos del "Derecho general de obligaciones y contratos” de los títulos I y II del libro IV (artículos 1088-1314), donde

${ }^{22}$ Como afirma Luis Díez-Picazo: "la modificación más importante nos parece es la relativa al capítulo que se refiere al incumplimiento de las obligaciones”, Luis DíEz PicAzo, "La propuesta de modernización del derecho de las obligaciones y contratos", en Boletín del Ministerio de Justicia, año LXv, No 2130, Madrid, abril, 2011.

${ }^{23}$ La estructura general de la propuesta de modernización coincide, además, con la de los Principios UNIDROIT y de los PECL. En efecto, el capítulo séptimo de los Principios UNIDROIT, titulado "Incumplimiento", se divide en cuatro secciones: "Incumplimiento en general"; "Derecho a reclamar el cumplimiento"; "Resolución" y "Resarcimiento". Y en los PECL, el capítulo octavo se rubrica "Non-Performance and Remedies in General" y su capítulo noveno "Particular Remedies for Non-performance" y este último se divide en cinco secciones: "Right to performance"; "Withholding Per- formance"; "Termination of the Contract"; "Price Reduction" y "Damages and Interest".

${ }^{24}$ Fenoy Picón (n. 8), pp. 68-69. 
perviven, sin ninguna modificación significativa, los textos iniciales promulgados y puestos en vigor en $1889^{25}$. Sigue precisando que sería exagerado hablar de una necesidad de reforma y, más aún, de una reforma perentoria, pues si este importantísimo sector del ordenamiento jurídico-privado ha solucionado por vía de jurisprudencia y doctrina los conflictos planteados, podrá continuar haciéndolo en el futuro; sin embargo, no se desconoce la conveniencia de la reforma que se proyecta, pues ésta es indiscutible ${ }^{26}$.

Añade la Exposición de motivos, que en el Código Civil la materia de las obligaciones y de los contratos no fue objeto de especial empeño por parte del legislador, pues otras cuestiones preocupaban entonces, y toda reflexión sobre este ámbito del Derecho fue más bien superficial ${ }^{27}$.

Los cambios habidos en el siglo xx han incidido en el sector de los contratos y ello ha impulsado el nacimiento de cuerpos de Derecho que se ocupan de esta temática, sirviéndose de nuevos puntos de vista y criterios $^{28}$. Tales cuerpos de Derecho son la Convención de Viena, los Principios UNIDROIT y los PECL y una serie de directivas de la Unión Europea que, aunque directamente relacionadas con los contratos de consumo o contratos con consumidores, han supuesto un núcleo del Derecho Contractual europeo que impone la necesidad de coordinarlo con el resto del ordenamiento ${ }^{29}$.

Con relación a la Convención de Viena, se precisa que ella abrió el 254 camino al marcar, de forma muy notoria, un importante grado de evolución en el Derecho general de las Obligaciones y Contratos con una notable aproximación entre los Derechos de origen anglosajón y los de cuño europeo continental y dentro de estos últimos, entre los situados en el campo del Derecho alemán y los que se podrían situar en el ámbito de influencia del Derecho francés. Se añade que la Convención de Viena fue proseguida por importantes tentativas de elaborar reglas comunes que representen algo así como el Derecho de Contratos de aceptación general en el tráfico comercial. Ocurre así con los Principios UNIDROIT y los PECL. Luis Díez-Picazo, refiriéndose a la influencia de estos cuerpos normativos, destaca que su

${ }^{25}$ Ministerio de Justicia, "Exposición de motivos”, en Propuesta para la modernización del Derecho de Obligaciones y Contratos, Madrid, Ministerio de Justicia, 2009, Apartado I, p. 8.

${ }^{26}$ Ministerio de Justicia, op. cit., Apartado iI, p. 9.

${ }^{27}$ Op. cit., Apartado II, p. 10. Luis Díez-Picazo, sobre el particular, expresa: "Es verdad, el llamado derecho de las obligaciones en la época en que se prepara y redacta el Código civil, se encontraba todavía en un estado no definitivo. Había nacido en las reflexiones que surgieron primero en la obra de Pothier, que fue el primero en escribir un Tratado de las Obligaciones, y después en la obra de Savigny, pero -todo hay que decirlo- tanto en un caso como en otro, lo que se hizo fue generalizar soluciones de los textos antiguos que contemplaban solamente algún tipo de obligación”. Se refiere a aquellas obligaciones que nacen de las estipulaciones. Dítz-Picazo (n. 22).

${ }^{28}$ Ministerio de Justicia (n. 25), Apartado iII, p. 10.

${ }^{29}$ Op. cit., Apartado IV, p. 11. 
importancia reside en que en ellos han participado juristas habituados al conocimiento del Derecho europeo continental en sus diferentes variantes y al Derecho anglosajón, y en algunos de estos textos se habría producido una mezcla o fusión de uno y otro sistema ${ }^{30}$.

La propuesta adiciona que todo ello ha provocado que algunos países de lo que se suele llamar el entorno europeo, hayan sentido la necesidad de poner al día su propia regulación y, en cierta medida, de colocarla en paralelo con las líneas por las que puede discurrir el futuro del Derecho europeo de contratos $^{31}$. De esta manera lo ha hecho Alemania, con la llamada Ley de Modernización del Derecho de Obligaciones del año 2001, que ha introducido muy profundas variaciones en su Código Civil, y similares movimientos se perciben en la república francesa y en algunos otros países europeos ${ }^{32}$. Este escenario aconseja que las ya centenarias normas de nuestro Código Civil en esta materia sean examinadas, reexaminadas y en lo necesario sustituidas por otras ${ }^{33}$.

Después de precisar las razones de una reforma no perentoria, pero sí necesaria, se expresan sus finalidades; ella no sólo busca adaptar la regulación de las obligaciones y los contratos a los tiempos actuales sino, también, persigue alcanzar una mayor aproximación del Derecho español a los ordenamientos europeos ${ }^{34}$.

En efecto, en primer lugar se trata de establecer reglas que resulten acordes con las necesidades apremiantes sentidas en los tiempos que corren, lo cual supone evitar la arbitrariedad que pudiera producirse en la aplicación de conceptos añejos y, al mismo tiempo, dotarlas de operatividad, de modo que de la suerte de los contratos y de las obligaciones resulte aquélla

${ }^{30}$ El autor expresa: "Son en este sentido especialmente importantes tres tipos de trabajos de características externas muy distintas, pero con un fondo común. Hay que referirse ante todo a la Convención de Viena sobre Compraventa Internacional de Mercaderías, que fue aprobada el año 1980 y que procedía de los trabajos de la UNCITRAL, que habían ya anunciado esa fusión parcial de los dos sistemas jurídicos. (...) Siguieron no muchos años después, los llamados Principios de los Contratos Comerciales Internacionales que elaboró el Instituto para la Unificación del Derecho Privado Europeo, comúnmente conocido por las siglas UNIDROIT. Y, finalmente, la elaboración de la Parte General de Obligaciones llevada a cabo por la llamada Comisión Lando, que había gozado del favor de la Unión Europea (...), que buscaba también la coordinación y la fusión entre el Derecho europeo continental y el Derecho anglosajón”, DíEz-PicAzo (n. 22).

${ }^{31}$ Ministerio de Justicia (n. 25), Apartado iil, p. 10.

${ }^{32}$ Op. cit., Apartado III, p. 10.

${ }_{33}$ Op. cit., Apartado III, p. 11.

${ }^{34}$ Así lo reconocen, Carmen Jerez Delgado y Máximo Pérez García. Los autores hablan de una armonización jurídica, haciendo alusión a la mencionada aproximación entre los diversos ordenamientos nacionales, especialmente en materia de obligaciones y contratos en el contexto europeo, a fin de agilizar el mercado y facilitar las operaciones transfonterizas. Jerez Delgado y Pérez García (n. 17), pp. 168 y 170. 
que concuerde mejor con el desarrollo económico. Y, en segundo lugar, se busca obtener la mayor aproximación posible del Derecho español a los ordenamientos europeos, tal y como éstos son concebidos hoy y así facilitar la celebración de las denominadas operaciones transfronterizas ${ }^{35}$. Este proceso se desarrollará en espera de una unificación de las normas de Derecho europeo de contratos que, en algún momento, podrá producirse ${ }^{36}$.

(2) La Exposición de motivos de la Propuesta destina su apartado $\mathrm{VIII}^{37}$ al incumplimiento y los remedios, consignando los principios en que se inspira la reforma y sus contornos más característicos. El punto de partida es la denuncia de los defectos de la regulación del incumplimiento contractual, tanto en el Código Civil español, como en otros Códigos Civiles decimonónicos, defectos que la Propuesta pretende corregir. Los Códigos del siglo XIX carecen de una regulación especial del incumplimiento con perfiles definidos y no organizan armónicamente los remedios y acciones que puede ejercitar el acreedor que lo padece ${ }^{38}$. Se encuentra pendiente el debate sobre los sistemas vigentes en materia de lo que se puede llamar de un modo genérico "responsabilidad contractual", siendo necesario decidir si ésta es de índole culpabilística, fundada en la culpa del deudor o si, por el contrario, presenta algunos rasgos de objetivación.

Se anuncia el abandono del favor debitoris, expresándose que este principio no es el mejor medio para hacer dinámica una economía, pasando al favor creditoris, máxima que se traduce en:

a) el deudor que incumple no se exonera cuando es no culpable, sino cuando hay justas causas de exoneración;

b) el acreedor dispone siempre de la pretensión de cumplimiento, salvo que la prestación sea imposible o especialmente onerosa y

c) el perjudicado puede siempre resolver el contrato cuando el incumplimiento sea esencial.

En síntesis, no es relevante si hay o no culpa del deudor y la causa de exoneración sólo incide en la indemnización de daños, no así en la procedencia de los restantes remedios.

La Exposición de motivos concluye señalando que el dibujo de los incumplimientos no es el mismo en cada uno de los remedios (acción de

${ }^{35}$ De manera similar, en la Exposición de motivos de la "Propuesta sobre contrato de compraventa": "La reforma que ahora se acomete viene requerida por una exigencia ineludible de modernización del Código civil, en una materia que sus principios inspiradores han ido distanciándose tanto de la evolución jurisprudencial de nuestro propio Ordenamiento, como de las nuevas corrientes del Derecho Uniforme y Comunitario”.

${ }^{36}$ Ministerio de Justicia (n. 25), Apartado iil, pp. 11-12.

${ }^{37}$ Op. cit., pp. 13-14.

${ }^{38}$ Díez-Picazo (n. 22) afirma: "no deja de ser extraño que en el Código Civil no exista una regulación ordenada del incumplimiento y que éste solo aparezca esporádicamente cuando es el punto central del tratamiento de las obligaciones". 
cumplimiento, resolución por incumplimiento, reducción del precio, pretensión de indemnización daños), pero que, sin duda, también puede tener vigencia un sistema que generalice la figura de la inejecución. Es importante conectar este apartado de la Exposición de motivos con aquélla incluida en la Propuesta de compraventa, en la que se lee:

"básicamente el nuevo sistema se caracteriza por utilizar un concepto unitario de incumplimiento del contrato y articular, adecuadamente, los remedios tradicionales con que cuenta en ese caso el acreedor".

\section{SECCIÓN II}

El régimen de la Propuesta de modernización del Código Civil ESPAÑOL Y LAS IDEAS CLAVES PARA LA CONSTRUCCIÓN DE UN SISTEMA DE REMEDIOS AL INCUMPLIMIENTO

Considerando el modelo de obligación imperante en el tráfico en el ámbito mundial y el diseño de la disciplina del incumplimiento en el Derecho de Contratos europeo e internacional, en especial los PECL, la Convención de Viena y los Principios de UNIDROIT, las ideas clave para la construcción de un sistema de remedios al incumplimiento, coherente, funcional al interés del acreedor perjudicado y adecuado a las actuales condiciones de la actividad contractual, son las que siguen:

(1) la comprensión del contrato,

(2) la noción unitaria de incumplimiento y

(3) la pluralidad de remedios del acreedor y la opción entre ellos.

En esta sección se examinará el régimen del incumplimiento contractual de la Propuesta de modernización, con la finalidad de verificar si están presentes en él las ideas claves de que se habla.

\section{(1) La comprensión del contrato}

El contrato no se concibe sólo como un instrumento creador de derechos y obligaciones sino, también, como mecanismo de organización y satisfacción del interés de las partes. Se habla de una noción más realista del contrato ${ }^{39}$,

${ }^{39}$ Antonio Morales Moreno ha destacado que este enfoque realista es el único que permite rescatar el propio concepto de negocio jurídico de los peligros de una excesiva abstracción. Antonio Manuel Morales Moreno, "El 'propósito práctico’ y la idea de negocio jurídico en Federico de Castro", en Antonio Manuel, Morales Moreno, Modernización del Derecho de obligaciones, Madrid, Civitas, 2006, pp. 323, 326. Antes publicado en Anuario de Derecho Civil, fascículo Iv, volumen 36, Madrid, 1983. En Chile Álvaro Vidal Olivares, "La construcción de la regla contractual en el derecho civil de los contratos", en RPUCV, 
que no lo entiende sólo como un dispositivo de creación de relaciones jurídicas, aunque también le corresponda ese cometido, sino como algo más complejo y de más amplio alcance: como un medio a disposición de los particulares para organizar sus propios intereses y conseguir la satisfacción de los mismos ${ }^{40}$. En efecto, el contrato, primero que todo, se ocupa de la organización, regulación y la ulterior satisfacción de los intereses de las partes. Éstas, al contratar, buscan la consecución de un propósito práctico que sólo obtendrán con el cumplimiento fiel y oportuno del contrato, propósito que interesa en la medida que se hubiere incorporado, explícita o implícitamente, a la regla contractual ${ }^{41}$.

Este propósito práctico permite al intérprete dibujar, para cada caso particular, el interés del acreedor, al que se le denomina "interés contractual" y que el contrato hace objeto de su protección. El fin del contrato es la satisfacción del interés contractual ${ }^{42}$ y se realizará en forma natural con la ejecución de la prestación prometida; tal ejecución constituye el medio necesario para la obtención de dicha satisfacción.

¿Recoge la Propuesta esta concepción realista del contrato?

Si se está al concepto de contrato y a las reglas sobre su contenido y eficacia ${ }^{43}$, no se advierte diferencia sustancial con el régimen legal vigente en España; sin embargo, de un examen detenido de la Propuesta surge la necesidad de atender no sólo a los derechos y obligaciones que el negocio produce (la regla o precepto contractual) sino, también, al propósito o finalidad perseguida por las partes.

Así, en la ordenación de la causa, el artículo 1238 exige considerar los propósitos prácticos acordados por las partes con el objetivo de determinar el régimen jurídico aplicable al contrato. La:

No 21, Valparaíso, 2000, pp. 209-212 y Jaime AlCALDE Silva, "La causa de la relación obligatoria”, en Alejandro GuZmán Brito (ed.), Estudios de Derecho civil III, Santiago, Legal Publishing, 2008, pp. 342-358.

${ }^{40}$ Morales Moreno (n. 39). En la misma dirección Francesco Messineo, Il contratto II. Diritto privato, teoria generale, Milano, Giuffrè editore, 1968, p. 813

${ }^{41}$ Para Federico de Castro el propósito práctico que ha sido materia de consentimiento o se da por consentido, permite desentrañar de mejor manera la voluntad de las partes y hace plausible los motivos que ellas han incorporado al contrato y que aspiran alcanzar o satisfacer con su cumplimiento fiel y oportuno. Federico DE CASTRO y BRAVO, El negocio jurídico, 1985, reimpreso en Madrid, Instituto Nacional de Estudios Jurídicos, 2002, pp. 29, 228-229. En el mismo sentido Luis Díez-PiCAzo y Ponce De León, "El concepto de causa en el negocio jurídico", en Anuario de Derecho Civil, fascículo 1, volumen 16, Madrid, 1963, p. 32.

${ }^{42}$ Cfr. Luis Díez-Picazo y Ponce de León, "Prólogo", en Vicente Espert Sanz, La frustración del fin del contrato, Madrid, Tecnos, 1968, pp. 10-11.

${ }^{43}$ Capítulo primero "Disposiciones generales" del título II "De los contratos", artículos 1236-1244. 
"Propuesta civil recoge un conocido concepto para la civilística española: el del 'propósito práctico del contrato', tomado del pensamiento de Federico de Castro y Bravo" ${ }^{44}$.

Si bien la Propuesta conceptualiza al contrato como órgano creador de obligaciones de dar, hacer o no hacer ${ }^{45}$, cuando define en general a la obligación recoge una comprensión más amplia de la misma, centrada no sólo en el deber de conducta del deudor sino, también, en el resultado esperado por el acreedor. En efecto, se prevé que la realización de la prestación -objeto de la obligación- en cualquier caso debe satisfacer el interés legítimo del acreedor en ella ${ }^{46}$. Reconoce el Proyecto, que unido de manera indisoluble a la prestación objeto de la obligación, se halla un interés que el acreedor persigue satisfacer y que es también parte integrante de la misma. En efecto, el artículo 1088 de la Propuesta dispone:

"En virtud de la obligación, el acreedor tiene derecho a exigir una prestación que puede consistir en dar, hacer o no hacer alguna cosa -y sigue- la prestación, aunque no tenga contenido económico, ha de satisfacer un interés legítimo del acreedor".

Esta concepción incide tanto en el alcance de la prestación -norma de conducta-, como en el cumplimiento e incumplimiento por parte del deudor $^{47}$. Por una parte, el deudor compromete toda la actividad que sea razonable según el contrato, para que el acreedor satisfaga su interés ${ }^{48}, y$

${ }^{44}$ Fenoy Picón (n. 8), p. 106.

${ }^{45} \mathrm{El}$ artículo 1092 de la Propuesta prescribe que las obligaciones nacen, entre otras fuentes, de los contratos. Y según su artículo 1236, por el contrato, dos o más personas acuerdan crear, modificar o extinguir relaciones jurídicas patrimoniales y establecer reglas para las mismas. Por último, el artículo 1243 delimita el efecto contractual prescribiendo que los contratos obligan no sólo al cumplimiento de lo expresamente pactado sino, también, a todas las consecuencias que, según su naturaleza, sean conforme a la buena fe, al uso y a la ley.

${ }^{46}$ Cfr. Jerez Delgado y Pérez García (n. 17), p. 174. "Especialmente importante es la introducción en el Código Civil de una perspectiva más amplia de la obligación. Se define la esencia de cualquier obligación con el carácter general como el deber de satisfacer el interés legítimo del acreedor. No se contempla la obligación ya desde la perspectiva exclusiva del deudor, que ha de dar, hacer o no hacer algo determinado, sino también desde la perspectiva del acreedor, cuyo interés legítimo ha de quedar satisfecho".

${ }^{47}$ Morales Moreno (n. 11), p. 19, sostiene que la nueva construcción del Derecho de Obligaciones contractuales tiende a reforzar la idea de garantía de un resultado -la satisfacción del interés del acreedor-, que traspasa los límites de la idea de cumplimiento del deber de prestación.

${ }^{48} \mathrm{El}$ artículo 1167 dispone que si el deudor ejecuta una prestación diferente a la debida para que el acreedor se haga pago mediante la realización del objeto de aquélla, la obligación se extingue en la medida en que el acreedor quede satisfecho con su realización. 
por otra, se entenderá que ejecuta la obligación, extinguiéndola por medio del cumplimiento, sólo cuando el acreedor alcance tal satisfacción; de lo contrario, se verificará el incumplimiento que producirá los efectos queridos por las partes o, en su defecto, los del artículo 1188 y siguientes.

De esta manera, pese a que formalmente no existe disposición en la Propuesta, en ésta el cumplimiento y el incumplimiento están de manera íntima ligados a la satisfacción, en un caso, y a la insatisfacción, en otro, del interés del acreedor. Cobra relevancia el propósito de este último y su interés contractual. Así, si el deudor cumple voluntariamente la obligación, satisfaciendo el interés del acreedor, su propósito se desvanece al tiempo de su consecución y pasa desapercibido; empero, si el deudor incumple, tal propósito aflora y es relevante para modular los efectos que tal inejecución producirá, su procedencia y alcance. Por ejemplo, para la resolución se requiere de un incumplimiento esencial y su definición requiere tomar en cuenta la finalidad del acreedor ${ }^{49}$. La procedencia de este remedio exige apreciar la proyección del acreedor incorporada en el contrato. Aquí, el propósito incide en el surgimiento del remedio. Ahora, si se reclama la indemnización de daños, su extensión la fija el criterio de la razonable previsibilidad al momento de contrato (artículo 1208), que se dibujará según sea el conocimiento real (lo que conocía) o imputado (lo que debía conocer) del deudor en ese momento, en lo concerniente a la finalidad o propósito perseguido por el acreedor al contratar. Así, salvo asunción de riesgo diversa, el deudor responderá por aquellos daños que se sigan de la frustración de la finalidad o propósito usual, atendido el sector del tráfico relevante.

\section{(2) Noción unitaria de incumplimiento}

El incumplimiento se entiende como un hecho amplio y objetivo que causa la insatisfacción del interés del acreedor ${ }^{50}$. Sus efectos están estrechamente vinculados con el impacto que éste produce en el interés del contratante y su objeto común consiste en servir de cauce para que el acreedor, no

${ }^{49}$ Artículo 1199: "Cualquiera de las partes de un contrato podrá resolverlo cuando la otra haya incurrido en un incumplimiento que, atendida su finalidad, haya de considerarse esencial".

${ }^{50}$ Cfr. Morales Moreno (n. 11), p. 19: “(...) Hoy podemos afirmar que la nueva construcción del derecho de obligaciones contractual tiende a reforzar, en la vinculación contractual, la idea de garantía de un resultado, que traspasa los límites de la idea de cumplimiento del deber de prestación”; más adelante agrega: “ (...) que la culpabilidad no tiene que ser un ingrediente necesario del propio concepto de incumplimiento, sino que éste consiste, lisa y llanamente, en la falta de ejecución (o falta de realización) de las exigencias del contrato, con la consiguiente insatisfacción del interés del acreedor”. 
obstante el incumplimiento, alcance su satisfacción. Los remedios -así se denomina a tales efectos- se articulan a partir de esta idea de incumplimiento, amplia y objetiva ${ }^{51}$.

El derecho uniforme de la contratación, pienso en la Convención de Viena, en los Principios UNIDROIT y los PECL, instala esta noción unitaria de incumplimiento, amplia y objetiva, que encierra toda manifestación de inejecución, sin interesar que el deudor se halle, o no, exonerado de responsabilidad $^{52}$. Se prescinde del estándar de conducta del buen padre de familia y seguidamente, de la culpa; aunque de todas formas se prevé un modelo de conducta que permite medir si el deudor observó o no el comportamiento debido -la figura de la persona razonable- en su lugar y circunstancias ${ }^{53}$.

Así, los artículos 45 y 61 de la Convención de Viena articulan los remedios del acreedor afectado a partir del incumplimiento de cualquiera de las obligaciones que le incumben al deudor; el artículo 25 define el incumplimiento esencial del contrato; y el artículo 79 (5) expresamente limita el ámbito de aplicación de la causa de exoneración (impedimento ajeno al razonable control del deudor) a la indemnización de daños, sin privar al acreedor de los restantes remedios, como la resolución, la reparación, sustitución o la rebaja del precio. Hay incumplimiento con independencia

${ }^{51}$ En la doctrina española, el primero en plantear la necesidad de construir un concepto unitario de incumplimiento - una noción amplia y objetiva- fue PANTAleón Prieto (n. 13), pp. 1.720-1.721, quien afirma: "La primera premisa de un derecho del incumplimiento contractual congruente valorativamente y altamente eficiente es la previsión de una disciplina sustancialmente unitaria para toda desviación del programa contractual: de un conjunto de remedios o medios de tutela del acreedor sustancialmente común para los casos de imposibilidad de la prestación, sobrevenida u originaria, mora y cumplimiento defectuoso, incluyéndose en éste la evicción y las cargas, los defectos de calidad o de cabida del inmueble vendido, y los llamados 'vicios ruinógenos' en el contrato de obra". Le sigue, Morales Moreno (n. 15), pp. 29-30. El autor asevera que el incumplimiento "consiste en la falta de ejecución o realización de las exigencias del contrato, en cualquiera de sus manifestaciones. Tal amplitud permite integrar, en un sistema único, la pluralidad de sistemas de responsabilidad contractual (en sentido amplio) que encontramos en el Código Civil. De este modo, podemos hacer desaparecer los sistemas especiales de responsabilidad que implican los saneamientos. La mora y la imposibilidad pasan a ser consideradas como manifestaciones del incumplimiento; y la resolución, como remedio, entre otros, del incumplimiento". Morales Moreno (n. 11), pp. 32-33; Luis Díez-Picazo, Fundamentos de Derecho Civil Patrimonial II. Las relaciones obligatorias, 6 $^{\text {a }}$ ed., Navarra, Aranzadi Civitas, 2008, p. 654. En Chile Álvaro Vidal Olivares, "Cumplimiento e incumplimiento contractual en el Código Civil. Una perspectiva más realista”, en Revista Chilena de Derecho, volumen 34, $\mathrm{N}^{\circ}$ 1, Santiago, 2007, p. 48 y ss. y Mejías Alonzo (n. 6), pp. 459-478.

${ }^{52}$ Fenoy Picón, La falta de conformidad... (n. 16), p. 200.

${ }^{53}$ Véase Álvaro VIDAL Olivares, "La noción de persona razonable en la compraventa internacional", en Antonio Cabanillas Sánchez (ed.), Estudios Jurídicos en Homenaje al profesor Díz Picazo y Ponce de León, Madrid, Civitas, 2003, tomo II. 
de si el deudor está amparado, o no, en la causa de exoneración del citado artículo 79 (1) de la Convención de Viena. Sin embargo, este instrumento no ofrece una definición de incumplimiento, a diferencia de lo que sí sucede en los principios aludidos. En efecto, el artículo 7.1.1. de los Principios UNIDROIT indica que el incumplimiento

“consiste en la falta de ejecución por una parte de alguna de sus obligaciones contractuales, incluyendo el cumplimiento defectuoso o el cumplimiento tardío" ${ }^{54}$.

El concepto es simplificador y aglutinador de las distintas modalidades del incumplimiento ${ }^{55}$. Por su parte, el artículo 1:301 (4) de los PECL lo define en términos de denotar

"cualquier incumplimiento de una obligación derivada del contrato, esté o no justificada, e incluye el cumplimiento tardío o defectuoso, así como la inobservancia del deber de colaborar para que el contrato surta plenos efectos".

El incumplimiento comprende cualquier desviación del cumplimiento, 262 desde la total inactividad del deudor hasta cualquiera falta de conformi$\operatorname{dad}^{56}$. Es un concepto unificador que equipara jurídicamente todas las

${ }^{54}$ Cfr. Instituto de Investigaciones Jurídicas Centro Mexicano, Comentario al artículo 7.1.1 Principios de Unidroit sobre contratos comerciales internacionales 2004, en www.bibliojuridica.org/libros/libro.htm?l=2488, p. 200, visitado el 29 de diciembre de 2010; Luis Paes de Barros LeÃes, "Notas sobre la inexecução", en Michael JoachimBonell, Principi per $i$ contratti commerciali internazionali e il sistema giuridico latinoamericano, Padova, Cedam, 1996, pp. 279-280; Michael Joaquim Bonell, I Principi Unidroit nella practica. Casistica e bibliografia riguardanti i principi unidroit dei contratti commerciali internazionali, Milano, Giuffrè, 2002, pp. 326-327.

${ }_{55}^{5}$ Cfr. Fenoy Picon, La falta de conformidad... (n. 16), pp. 183-187, 222.

${ }^{56}$ Esta noción de incumplimiento, como lo destaca Antonio Morales Moreno, comprende, incluso, los casos de imposibilidad inicial, porque el incumplimiento no se predica de la conducta debida del deudor (en cuyo caso podría pensarse: "impossibilium nulla obligato est"), sino del contrato: es la falta de realización del mismo. El incumplimiento pone de manifiesto el problema de insatisfacción del interés del acreedor y abre el camino a la respuesta del ordenamiento, orientada al reparto de ese riesgo entre los contratantes, a través del sistema de remedios que integran el contenido de la responsabilidad contractual (en el sentido amplio que él emplea). Cfr. Morales Moreno (n. 11), p. 26. En el Comment D del precepto transcrito se dice que el término incumplimiento cubre cualquier falta en el cumplimiento y por cualquier causa, abarcando las posibles formas de no realizarlo, como la total inactividad o que la conducta deudor no se conforme con el contrato, por ejemplo, porque se hace tarde, de manera incompleta o de cualquier otra forma es defectuosa. THE COMMISSION ON European Contract Law, Lando, Beale (eds.), “Comment D del art. 1:301 PECL” (n. 3), p. 124. 
manifestaciones de la inobservancia, siendo indiferente si el deudor está o no exonerado de responsabilidad ${ }^{57}$.

¿Qué concepto de incumplimiento ofrece la Propuesta?

El capítulo VII contiene la disciplina del incumplimiento y su sección primera incluye disposiciones generales, entre las cuales, está la definición de éste. El artículo 1188 señala que hay incumplimiento cuando el deudor no realiza con exactitud la prestación principal o cualquier otro de los deberes que de la relación obligatoria resulten.

La comprensión de esta definición exige conectar la disposición con aquéllas que conceptualizan obligación (art. 1088), cumplimiento (art. 1153) y la que fija la extensión del contenido de la regla contractual (art. 1243). Como se ha explicado, la obligación impone al deudor, en último término, el deber de realizar la prestación de modo de que el acreedor satisfaga su interés y, en consecuencia, se entiende que el deudor cumple la obligación cuando realiza la prestación en forma completa; asimismo, en el caso de la obligación contractual, ella no se extiende sólo a lo expresamente pactado sino, también, a todas las consecuencias que, según su naturaleza, se conformen con la buena fe, el uso y la ley. Para responder si el deudor ha cumplido o no, el operador previamente debe fijar el contenido de la regla contractual o, si se quiere, de la obligación con origen en la misma.

La noción de incumplimiento es amplia y objetiva ${ }^{58}$, coincidiendo con aquélla de los Principios UNIDROIT y los PECL, aunque el último de estos ordenamientos no precisa de un modo expreso si hay incumplimiento con independencia de si éste es, o no, excusable para el deudor. No obstante esta omisión, se concluye el carácter neutral u objetivo del incumplimiento a partir de la disposición del inciso final del artículo 1209 de la Propuesta que precisa, al igual que el artículo 79 (5) de la Convención de Viena, que la causa de exoneración no impide al acreedor el ejercicio de cualquier otro

${ }^{57}$ Diez-Picazo, Roca Trías, Morales Moreno (n. 3), p. 317.

${ }^{58}$ En la doctrina española, Nieves Fenoy, siguiendo a Morales Moreno (n. 15), pp. 29-30, sostiene que los rasgos que caracterizan el incumplimiento de la Propuesta de modernización son tres: (1) la adopción de una noción amplia y unitaria de incumplimiento; (2) El incumplimiento implica la insatisfacción del interés del acreedor incorporado al contrato, lo que se traduce en que el deudor incumple, tanto si lo que no ejecuta son sus obligaciones (contractuales) o deberes de prestación cuanto si no se logra el resultado fáctico de la existencia o inexistencia de ciertos estados de la realidad incorporados tanto al contrato como garantizados por el deudor al acreedor. Por ejemplo, se asegura y garantiza que el cuadro que se vende es de cierto autor (atribución de una cualidad al objeto), comprobándose después que es de otro artista, de inferior valor en el mercado de obras de arte y (3) que es un concepto neutro desde el punto de vista de la imputación subjetiva al deudor. Basta constatar que ha habido una divergencia entre lo materialmente ejecutado y lo diseñado y exigible según el contrato, para que pueda decirse que el deudor ha incumplido. Esta noción incluye el incumplimiento inexcusable y el excusable. Fenoy Picón (n. 8), p. 70. 
derecho distinto del de exigir la indemnización de daños y perjuicios que le pueda corresponder conforme al Código Civil (inciso final). En la Propuesta, el incumplimiento excusable también permite al acreedor hacer uso de los remedios frente al mismo, salvo el de la indemnización de daños.

Para la sección primera de la Propuesta, el incumplimiento relevante es aquél que tiene su causa en la acción u omisión del deudor, privando al acreedor del derecho a invocarlo cuando se ha originado, exclusivamente, en su propia conducta (inciso $2^{\circ}$ artículo 1188) ${ }^{59}$. La Propuesta no se pronuncia, al igual que la Convención de Viena y a diferencia de los Principios de UNIDROIT $^{60}$ y los PECL ${ }^{61}$, sobre la contribución del acreedor, junto con la del deudor, a la producción del daño causado por el incumplimiento; esto es, cuando ambas conductas constituyen una concausa de tal daño. A pesar del silencio de la Comisión de Codificación, la contribución del acreedor no debiera incidir en todos los remedios, sino sólo en la indemnización de daños, rebajándola por causalidad ${ }^{62}$.

Dentro de la acción u omisión del deudor se comprende la conducta de los terceros de cuya colaboración, o auxilio, éste se hubiere servido para el

${ }^{59}$ La regla del inciso $2^{\mathrm{o}}$ del artículo 1188 coincide con la de los artículos 80 de la Convención de Viena, 7.1.2. de los Principios UNIDROIT (interferencia de otra parte) y 8:101 (3) (Remedios disponibles) de los PECL. El primero dispone que "una parte no podrá 264 invocar el incumplimiento de la otra en la medida que tal incumplimiento haya sido causado por acción u omisión de aquélla"; el segundo que "Una parte no podrá ampararse en el incumplimiento de la otra en la medida en que tal incumplimiento haya sido causado por acción u omisión de la primera o por cualquier otro acontecimiento por el que ésta haya asumido el riesgo"; y el tercero que "A party may not resort to any of the remedies set out in Chapter 9 to the extent that its own act caused the other party's non-performance" En el Comment B del artículo 8:101 de los PECL se precisa, que el incumplimiento causado por un acto u omisión del acreedor tiene efectos sobre los remedios de que pueda disponer. Sería contrario a la buena fe, que aquél dispusiera de un remedio, cuando precisamente ha sido él el responsable del incumplimiento. The Commission on European Contract Law, Lando, Beale (eds.), “Comment B (iii) del art. 8:101 PECL” (n. 3), p. 361.

${ }^{60}$ Artículo 7.4.7 de los Principios UNIDROIT “(Daño parcialmente imputable a la parte perjudicada) Cuando el daño se deba en parte a un acto u omisión de la parte perjudicada o a otro acontecimiento por el que esa parte asume el riesgo, la cuantía del resarcimiento se reducirá en la medida en que tales factores hayan contribuido al daño, tomando en consideración la conducta de cada una de las partes”.

${ }^{61}$ Artículo 9:504 PECL “(Loss Attributable to Aggrieved Party). The non-performing party is not liable for loss suffered by the aggrieved party to the extent that the aggrieved party contributed to the non-performance or its effects".

${ }^{62}$ Cfr. Pablo Salvador Coderch, "Comentario al artículo 80 de la Convención de Viena", en Luis Dítz-PicAzo (director y coordinador), La compraventa internacional de mercaderías. Comentario de la Convención de Viena, Navarra, Civitas, 1998, pp. 657-658. Para el caso de la causación conjunta del incumplimiento se inclina por la reducción de la indemnización de daños. Véase también Thomas Neumann, "Shared Responsibility under Article 80 CISG", in NordicJournal Commercial Law, No 2, 2009, disponible en internet en http://www.njcl.fi/2_2009/ neumann_thomas.pdf, sitio web visitado el 3 de marzo de 2011. La solución propuesta por el autor es la misma que la de los Principios UNIDROIT apoyándose en el principio de buena fe objetiva y en la norma de integración del artículo 7 (2) de la Convención de Viena. 
cumplimiento (artículo 1189) ${ }^{63}$. La propuesta imputa los actos u omisiones del tercero al deudor como si los hubiera realizado él mismo, de modo que si éstos o aquéllas fueran la causa del incumplimiento, el acreedor queda facultado para dirigirse en contra del deudor, sin que éste pueda aducir como excusa el hecho del tercero ${ }^{64}$.

El incumplimiento en la Propuesta, siguiendo el modelo de la Convención de Viena y la directiva 44/99, absorbe la situación de los vicios materiales y jurídicos de la cosa objeto de la prestación, sometidos hasta ahora al régimen especial de las acciones de saneamiento y al de la imposibilidad inicial de la prestación constitutiva de causa de nulidad por falta de objeto. Así, en la Exposición de motivos de la Propuesta de contrato de compraventa se lee:

"Los saneamientos, como regímenes especiales, desaparecen y son sustituidos por una nueva regulación de los problemas de acuerdo con las reglas generales del derecho de obligaciones" ${ }^{65}$.

El artículo 1445 de esta Propuesta, dispone que por la compraventa el vendedor se obliga a entregar una cosa que sea conforme al contrato y esté libre de derechos de terceros que no hayan sido contemplados en él, y el comprador a pagar un precio en dinero y a recibirla en las condiciones estipuladas. Desaparece el fraccionamiento de las obligaciones que permite la distinción entre principales y secundarias, o aquéllas que son de la esencia

${ }^{63}$ Fenoy PiCón (n. 8), p. 98. "El artículo 1189 PC recoge una regla de imputación del incumplimiento al deudor, que opera de modo neutral. En el mundo de los contratos, no habiéndose pactado una obligación personalísima o, no habiendo prohibición pactada, el deudor puede encargar a un tercero, total o parcialmente, el cumplimiento del contrato. Esto es algo habitual en una sociedad de servicios como la actual. Con independencia del tipo de relación que el deudor y el tercero mantengan, la Propuesta civil establece que la actividad de ese tercero (el acto, la omisión) se imputa al deudor a efectos del incumplimiento. El deudor asume jurídicamente la actuación desenvuelta en su propio beneficio empresarial por el auxiliar o por el tercero contratado".

${ }^{64}$ La misma solución da el artículo 8:107 de los PECL al prescribir que: "A party who entrusts performance of the contract to another person remains responsible for performance". La Convención de Viena da una regla distinta en su artículo 79 (2), permitiendo la exoneración del deudor cuando la causa del incumplimiento ha sido el hecho de un tercero encargado, siempre que se acrediten la concurrencia de las condiciones de exoneración, tanto para el propio deudor como para el tercero. Sobre esta regla en la Convención de Viena y su alcance, véase Álvaro Vidal Olivares, "La responsabilidad del deudor por incumplimiento de su tercero encargado en la compraventa internacional de mercaderías", en Cuadernos de Análisis Jurídico, Santiago, Ediciones de la Universidad Diego Portales, Colección de Derecho Privado, 2006 vol. III.

${ }^{65}$ Ministerio de Justicia, "Exposición de motivos de la Propuesta de modificación del Código civil en materia de compraventa”, en Boletín de Información, No 1988, Madrid, Ministerio de Justicia, 2005, p. 109. 
de las que no lo son. La obligación refiere al contrato y, de aplicar el artículo 1088 de la Propuesta de modernización, la infracción de cualquiera de estas obligaciones constituye incumplimiento y pone a disposición del acreedor los remedios frente al mismo. El artículo 1474 impone al vendedor el deber de conformidad, al exigirle la entrega de una cosa de acuerdo con lo estipulado en cantidad, calidad y tipo y que deberá estar envasada o embalada en la forma que resulte del contrato Los artículos 1475 a 1480 definen cuándo se entiende que hay falta de conformidad ${ }^{66}$; el artículo 1481 hace responsable al vendedor de toda falta de conformidad que exista al tiempo de la transmisión del riesgo al comprador ${ }^{67}$; y el artículo 1482 reconoce al comprador los remedios a la falta de conformidad: el derecho a exigir el cumplimiento, reducir el precio o resolver el contrato, más la indemnización de daños si procediere $^{68}$. Por su parte, el artículo 1490 hace aplicable a los vicios jurídicos los remedios por la falta de conformidad del artículo 1482 .

Dentro de la misma idea de concebir el incumplimiento como un hecho amplio, el artículo 1303 de la Propuesta dispone que no afecta la validez del contrato el mero hecho de que en el momento de su celebración no sea posible el cumplimiento de la obligación de alguna de las partes o que uno de los contratantes carezca de la facultad de disponer de los bienes objeto del mismo ${ }^{69}$. La norma es prácticamente idéntica a los artículos 3.3 de los Principios de UNI266 DROIT ${ }^{70}$ y 4: 102 de los PECL ${ }^{71}$. Las preguntas que surgen son, ¿̇se excluye la

${ }^{66}$ Cfr. Convención de Viena, artículo 35.

${ }^{67}$ Cfr. Op. cit., artículo 36.

${ }^{68}$ Cfr. Op. cit., artículos 45 (remedios al incumplimiento del vendedor), 46 (pretensión de cumplimiento específico), 47 (resolución); y 50 (rebaja del precio).

${ }^{69}$ Fenoy Picón (n. 8), p. 103 sostiene: "la norma del artículo 1303 PC rompe con el sistema del Código Civil (...). En el Código Civil se recoge una regla tradicional: Impossibilium nulla obligatio est (D. 50, 17, 185). El artículo $1261.2^{\circ} \mathrm{CC}$ señala que no hay contrato (invalidez), si no hay objeto cierto que sea materia del contrato y, según el artículo 1272 CC, ‘[n]o pueden ser objeto de contrato las cosas o servicios que sean imposibles'. En la Propuesta civil, en cambio, no se requiere para la validez del contrato que la prestación sea inicialmente posible. La misma regla se aplica -la de que no afecta a la validez- al hecho de que alguno de los contratantes carezca de facultad de disposición de los bienes en el momento de la perfección del contrato. Para este otro supuesto, la Propuesta civil también constituye una novedad, en el sentido de que habría un expreso pronunciamiento legal, pues entre nuestros autores se ha ido progresivamente asentando la idea de que en tal caso el contrato es válido".

${ }^{70} \mathrm{El}$ artículo 3.3 de los Principios UNIDROIT señala: “(Imposibilidad inicial) (1) No afectará a la validez del contrato el mero hecho de que al momento de su celebración fuese imposible el cumplimiento de la obligación contraída. (2) Tampoco afectará a la validez del contrato el mero hecho de que al momento de su celebración una de las partes no estuviere facultada para disponer de los bienes objeto del contrato".

${ }^{71}$ El artículo 4:102 de los PECL señala: "Initial Impossibility. A contract is not invalid merely because at the time it was concluded performance of the obligation assumed was 
nulidad del contrato? Y, al haber incumplimiento, ¿se aplican los efectos que le son propios? La respuesta a estas interrogantes se extrae del artículo $3^{\circ}$ de la Propuesta que modifica, en materia de compraventa, el párrafo primero del artículo 1460, quedando su texto como sigue:

"La imposibilidad de entregar la cosa por causa anterior a la celebración del contrato no impide al comprador que hubiera confiado razonablemente en su posibilidad ejercitar los derechos derivados del incumplimiento conforme al régimen de cada uno de ellos"72.

Quiere decir que si era razonable que el acreedor confiara en la posibilidad de cumplimiento, éste tiene la opción de ejercer, o los remedios al incumplimiento o la acción de nulidad por falta de objeto. De lo contrario, la cuestión queda sometida a las reglas de la nulidad del contrato ${ }^{73}$.

impossible, or because a party was not entitled to dispose of the assets to which the contract relates".

${ }^{72}$ En la Exposición de Motivos de la Propuesta sobre contrato de compraventa se lee: "La imposibilidad inicial ha sido considerada, tradicionalmente, en los Ordenamientos Europeos como una causa de nulidad del contrato. A ese criterio responde la redacción del párrafo primero del anterior artículo 1460. Pero el criterio se halla sometido a revisión. El hecho de que al tiempo de celebrarse el contrato de compraventa se haya perdido la totalidad de la cosa objeto de la misma no excluye necesariamente la existencia del contrato, puesto que el objeto no es tanto el real cuanto aquello sobre lo que han convenido las partes. La imposibilidad inicial no excluye que haya incumplimiento, con la aplicación de los consiguientes remedios, salvo la pretensión de cumplimiento. El vendedor debe responder del incumplimiento de este contrato, si ha hecho confiar al comprador en la existencia de la cosa”, Ministerio de Justicia (n. 65), p. 111.

${ }^{73}$ En el comentario 1 del artículo 3.3 de los Principios UNIDROIT se explica: "Contrariamente a lo establecido en numerosos sistemas jurídicos, que consideran nulo un contrato de compraventa si han perecido los bienes objeto del contrato al momento de su celebración, el parágrafo (1) de este artículo, de acuerdo con las tendencias más modernas, establece en términos generales que la validez del contrato no se ve afectada por el hecho de que en el momento de celebrarse la obligación contraída sea de cumplimiento imposible. Un contrato es válido aun cuando los bienes a los que se refiere hayan perecido al momento de contratar, con la consecuencia de que la imposibilidad originaria de cumplimiento se equipara a la imposibilidad que se presenta después de la celebración del contrato. Los derechos y obligaciones que surgen por la imposibilidad de cumplimiento de alguna o de ambas partes se determinarán de acuerdo a las normas sobre incumplimiento. Conforme a estas disposiciones podría tenerse en cuenta, por ejemplo, al hecho de que el deudor o el acreedor conocieran la imposibilidad de cumplimiento en el momento de celebrarse el contrato". Y se añade "Si la imposibilidad inicial de incumplimiento se debe a un prohibición legal ( $v$.gr. a una prohibición de exportación o de importación), la validez del contrato dependerá de si, conforme al derecho bajo el cual se ha dictado la prohibición, ésta tiene el propósito de invalidar o simplemente de impedir el cumplimiento del contrato. El parágrafo (1) también se aparta de algunos sistemas de tradición jurídica romanista que establecen el requisito de que el objeto del contrato sea posible". UNIDROIT, INSTITUTO INTERNACIONAL para la Unificación del Derecho Privado (n. 2), pp. 99-100. 
Respecto al carácter objetivo o neutro del incumplimiento, ya se ha anticipado que, si bien la definición del artículo 1188 no distingue según la inobservancia sea o no excusable al deudor, es posible afirmar tal carácter por cuanto la Propuesta prescinde, en general, de la imputación subjetiva. El incumplidor queda sujeto a los remedios cualquiera sea la causa del incumplimiento y con independencia de si éste se debe a la acción u omisión del propio deudor o de alguno de los auxiliares o terceros encargados. Digo en general, porque tratándose de la indemnización de daños sí interesa que el deudor pueda aducir un excusa suficiente para exonerarse del cumplimiento, privándole al acreedor del derecho a la misma. Sin embargo, esta excusa del artículo 1209, no afecta la procedencia de los restantes remedios ${ }^{74}$.

Otra manifestación de este carácter, se halla en materia de transmisión del riesgo de la cosa del vendedor al comprador. Los problemas del riesgo de deterioro o pérdida pasan a ser problemas de incumplimiento. En el No 3 de la Exposición de motivos de la Propuesta de compraventa se expresa:

"El anterior artículo 1452, dedicado a la regulación del riesgo en el contrato de compraventa, debe ser modificado para adaptarlo al sistema de regulación del incumplimiento contractual que adopta la reforma, sistema en el que se inspira la Directiva 1999/44 y que está presente en el Convención de Viena. Éste es también el sistema que se propone para la unificación de los derechos europeos en los Principios del Derecho Europeo de Contratos. Este nuevo sistema afecta al tratamiento del problema del riesgo en el contrato de compraventa. Toda pérdida o deterioro casual de la cosa, que ocurra antes del momento en que el vendedor haya cumplido su obligación de entregarla, es a riesgo del vendedor: la pérdida de la cosa provoca el incumplimiento de la obligación de entregar y el deterioro de la misma desemboca en el incumplimiento de la obligación de entregarla en conformidad con el contrato. El incumplimiento determina responsabilidad contractual, con la consiguiente aplicación de los correspondientes remedios. Esta construcción unitaria y objetiva del incumplimiento no deja espacio para separar entre incumplimientos imputables, a los que se aplicaría la doctrina del incumplimiento, e incumplimientos no imputables, a los que

${ }^{74}$ Coincide la solución de la Propuesta de modernización con aquélla de la Convención de Viena. En cambio, en los Principios UNIDROIT y los PECL la causa de exoneración alcanza no sólo a la indemnización de daños sino, también, al cumplimiento específico de la obligación incumplida. En verdad, estimo que el cumplimiento específico sólo se verá afectado por vía de consecuencia cuando el obstáculo impida el cumplimiento, no así cuando el supuesto sea de falta de conformidad, pudiendo el acreedor exigir la reparación o la sustitución de la prestación, sin que sea relevante la causa del incumplimiento. 
se aplicaría la doctrina del riesgo. El problema del riesgo ha de ser hoy tratado como un problema de incumplimiento".

Según el artículo 1452 de la Propuesta de modernización, el riesgo casual de la cosa corresponde al comprador desde que el vendedor haya hecho cuanto le incumba en el cumplimento de la obligación de entregar la cosa, agregando que el traspaso del riesgo al adquirente no priva a éste de los derechos que tuviera si la cosa entregada no se conformare con el contrato o no estuviere libre de derechos de terceros. Tal como dispone la Propuesta de compraventa en su artículo 1481, el vendedor responde de toda falta de conformidad existente al momento del traspaso del riego, aunque ella aparezca después de ese instante.

En síntesis, el incumplimiento entendido en sentido amplio, imputable subjetivamente o no al deudor, desde que implica la insatisfacción del interés del acreedor, pone a disposición de éste unos remedios cuya extensión será mayor o menor según sea la concreción del incumplimiento y si es o no imputable al deudor. Como afirma Nieves Fenoy, que la inejecución de la Propuesta de modernización sea una noción neutral, no impide que en la regulación de los remedios pueda decidirse si se tiene o no en cuenta la imputabilidad del deudor ${ }^{75}$.

\section{(3) Pluralidad de remedios y opción del acreedor}

El incumplimiento, entendido como hecho amplio y objetivo, permite articular una serie de remedios en favor del acreedor, entre los cuales optará con libertad, siempre que concurran sus condiciones de aplicabilidad. Se busca que el acreedor obtenga la satisfacción de su interés, pese al incumplimiento ${ }^{76}$. Entre estos remedios se hallan la pretensión de cumplimento específico, incluida la reparación y sustitución para la falta de conformidad; la reducción de precio generalizada para todos los cumplimientos imper-

${ }^{75}$ Fenoy Picón (n. 8), p. 81.

${ }^{76}$ Pantaleón Prieto (n. 13), pp. 1.728 y 1.737, habla de "medios de tutela frente al incumplimiento de que dispone el acreedor" y entre ellos considera: a) pretensión de cumplimiento, incluyendo la reparación de los vicios o defectos, la sustitución del objeto y cualquiera otra forma de corrección de la prestación defectuosa; b) remedios sinalagmáticos: resolución por incumplimiento, reducción del precio y la exceptio non adimpleti contractus; c) los remedios indemnizatorios; d) la pretensión restitutoria del enriquecimiento injustificado obtenida por el deudor a costa del acreedor; y e) el commodum representationis, en los casos de imposibilidad sobrevenida de la prestación imputable a una de las partes, remedio incompatible con la resolución, mas no así con la indemnización de daños. En esta misma dirección: Gema Díez-Picazo Giménez, La mora y la responsabilidad contractual, Madrid, Civitas, 1996 y, recientemente, Nieves Fenoy PiCón, "Sentencia de 10 de julio de 2003", en Cuadernos Civitas de jurisprudencia civil, N 68, Navarra, 2005. 
fectos; la resolución por incumplimiento y la indemnización de daños. Y pueden añadirse otros, como la excepción de contrato no cumplido, entendida como facultad del acreedor de suspensión del propio cumplimiento y el commodum representationis en supuestos de imposibilidad de la prestación $^{77}$.

El elemento que aglutina a estos remedios es el incumplimiento, al que se le suman unas condiciones configuradoras de sus supuestos de hecho. Así, en la resolución se requiere que el incumplimiento sea esencial, con independencia de la imputación subjetiva al deudor; y en la indemnización de daños, que la inejecución, cualquiera sea su entidad, sea imputable al deudor y lo será mientras no intervenga una causa de exoneración. Cada supuesto de hecho actúa como un verdadero filtro para la aplicación de los remedios por el incumplimiento ${ }^{78}$ y la opción de ejercitar uno u otro pertenece al acreedor, según mejor convenga a su interés afectado ${ }^{79}$. El principio de la fuerza obligatoria del contrato sirve de fundamento a la opción del acreedor frente a los remedios ${ }^{80}$. En efecto, el mismo contrato autoriza, producido que sea el incumplimiento, el tránsito desde realización

${ }^{77} \mathrm{El}$ commodum representationis es un remedio en virtud del cual el acreedor ante la imposibilidad de cumplimiento específico, incluso, por una causa no imputable al deudor, puede reclamarle la cesión de todos los derechos y acciones que tuviese en contra de terceros en razón del objeto de la prestación debida. Esta cesión no opera de pleno derecho, sino que es necesario que el acreedor la exija al deudor como una pretensión en el juicio respectivo, idéntica a la de indemnización, resolución o cumplimiento. El reconocimiento de este remedio al acreedor implica que el efecto de la imposibilidad sobrevenida no imputable al deudor es la extinción de la obligación, no así de la relación contractual, que subsiste, a menos que el acreedor resuelva el contrato. Véase Pantaleón Prieto (n. 13), pp. 1.021-1.022.

${ }^{78}$ Véase Vidal Olivares (n. 5), pp. 521-522.

${ }^{79}$ Reconociendo esta opción entendida como un verdadero poder de decisión del acreedor enfrentado a un abanico de remedios disponibles: Dílz-PicAzo (n. 51), p. 772; Díez-Picazo Giménez (n. 76), pp. 393-394; Fernando Pantaleón Prieto, "El sistema de responsabilidad contractual (Materiales para un debate)", en Anuario de Derecho Civil, fascículo 3, tomo XuIV, Madrid, 1991, p. 1.043. En Chile, justificando la opción a favor del acreedor, véase Vidal Olivares, La pretensión de cumplimiento... (n. 6), pp. 522-528.

${ }^{80}$ Carlos Pizarro Wilson, "Las cláusulas resolutorias en el Derecho civil chileno", en Cuadernos de Análisis Jurídico, Santiago, Ediciones de la Universidad Diego Portales, Colección de Derecho Privado, 2006, vol. III, pp. 247-249. El profesor Carlos Pizarro apoya la libre opción del acreedor en el principio de la fuerza obligatoria del contrato y, en último término, en la protección del interés del acreedor y afirma: "Este principio, el de la fuerza obligatoria, no debe entenderse como la necesidad de cumplir el contrato, sino que frente al incumplimiento, el acreedor debe escoger la sanción más adecuada para satisfacer su interés al momento de celebrar el contrato". Véase Vidal Olivares (n. 5), p. 522. En la doctrina española, reconociendo esta opción entendida como un verdadero poder de decisión del acreedor enfrentado a un abanico de remedios disponibles: Dífz-PicAzo (n. 51), p. 674; Díez-Picazo Giménez (n. 76), pp. 393-394 y Pantaleón Prieto (n. 79), p. 1.043. 
de la prestación convenida hacia los remedios, que conforman un abanico entre los que el acreedor optar libremente sin otro límite que sus condiciones de procedencia y el principio de la buena fe objetiva.

No obstante, pese a que la Convención de Viena ${ }^{81}$, los Principios UNIDROIT $^{82}$ y los PECL $^{83}$ reconocen al acreedor esta opción entre los remedios al incumplimiento, dejando atrás la tradicional ordenación jerárquica que privilegia la pretensión de cumplimiento sobre los restantes medios de protección, hoy en el Derecho Contractual europeo existen parcelas en las que se impone un orden de prelación al acreedor, trazando un camino de recorrido necesario para que obtenga la satisfacción de su interés. Es el caso del régimen de falta de conformidad de la Directiva 1999/44 y también de los PELS ${ }^{84}$. En estos dos cuerpos normativos el comprador afectado por una falta de conformidad debe necesariamente insistir en el cumplimiento del contrato, sea exigiendo la reparación o la sustitución de la cosa imperfecta, salvo que éste sea imposible o desproporcionado. Para el caso que no proceda la ejecución específica, o que el vendedor no lo haga dentro de plazo o ésta no pueda hacerse sin inconvenientes graves para el comprador, o que el vendedor declare que no la hará, recién, en ese momento, el comprador estará facultado para ejercitar los remedios al incumplimiento según sea su interés (resolución, reducción del precio, indemnización de daños e incluso, si insiste en el cumplimiento, la misma pretensión de reparación o sustitución ${ }^{85}$ ).

${ }^{81}$ Cfr. Convención de Viena, artículos 45 y 61.

${ }^{82}$ En el comentario del artículo 7.1.1 se señala que pese a que no existe una disposición en los Principios que así lo reconozca en forma expresa, el acreedor tiene derecho a optar entre los remedios y acumular aquellos que sean compatibles. UNIDROIT, INSTITUTO Internacional para la Unificación del Derecho Privado (n. 2), p. 201

${ }^{83}$ Cfr. PECL, artículos 8:101y 8:102.

${ }^{84}$ Study Group on a European Civil Code, Sales (PELS), prepared by Hondius, Ewoud, Heutger, Viola, Jeloschek, Christoph, Sivesand, Hanna, Wiewiorowska, Aneta, Principles of European Law on Sales, Munich, European Law Publishers, 2008. No es posible examinar los PELS sin acudir a los PECL; éstos constituyen la parte general de los primeros (artículos 1:201 y 4:101 de los PELS), sin perjuicio que en ellos se modifiquen expresamente algunas de las reglas de los PECL. Así ocurre en materia de remedios por incumplimiento. En efecto, los artículos 4:201 (Overview of remedies) y 4:205 de los PELS (Resort to other remedies) reconocen al comprador los remedios por entrega no conforme al contrato, estableciendo un orden jerárquico que privilegia el cumplimiento específico antes que los restantes remedios: resolución y reducción del precio. Para un análisis del sistema de remedios y la ordenación jerárquica entre ellos en los PELS, véase Nieves FEnOY Picón, "La entidad del incumplimiento en la resolución del contrato: análisis comparativo del artículo 1124 CC y del artículo 121 del Texto Refundido de Consumidores", en Anuario de Derecho Civil, fascículo 1, tomo LXII, Madrid, 2009, pp. 193-196.

${ }^{85}$ El apartado 4 del artículo 26 de la Propuesta de Directiva del Parlamento Europeo y del Consejo sobre derechos de los consumidores de 2008, deja claro que el consumidor 
Aunque parezca lo contrario, la distancia entre los dos sistemas -de ordenación jerárquica y los de libre opción- no es significativa, pues en los últimos se le reconoce al deudor un derecho a cumplir o subsanar su incumplimiento y la negativa del acreedor a la oferta del deudor debe ser, en todo caso, justificada ${ }^{86}$. La decisión legislativa de optar por uno u otro sistema pasa por una valoración de los intereses de las partes involucradas ${ }^{87}$. Un sistema de ordenación jerárquica como el descrito, aparentemente favorece el interés del deudor, al permitirle cumplir pese a su inobservancia, pero en el fondo también tiene en vista la pronta satisfacción del acreedor. En cambio, un sistema de libre opción incita a pensar que favorece el interés del acreedor, en desmedro de aquél del deudor; pero ello no es así, dado que lo que se hace es confiar en el buen criterio - uno razonable- del acreedor, puesto que al ser el afectado e interesado por alcanzar su satisfacción postergada por el incumplimiento, se inclinará por el remedio que mejor convenga a su fin. Si no actúa razonablemente en la elección, el mismo régimen del incumplimiento le hará sentir sus consecuencias negativas, ya sea privándole del ejercicio de alguno de los remedios o, bien, reduciendo el importe de la indemnización de daños (carga de mitigar las pérdidas). De cualquier forma, reconocer al acreedor la opción no implica necesariamente sacrificar la conservación del contrato, dado que para la procedencia de cada remedio es necesario la concurrencia de las condiciones que la determinan y la resolución, que es el remedio que mayor impacto produce en la eficacia del contrato, es, en todo caso, de aplicación excepcional y restringida.

¿Qué sucede en la Propuesta de modernización española?

sigue disponiendo de la posibilidad de exigir el cumplimiento, aunque lo haya solicitado antes y no haya tenido éxito. Hay una excepción lógica, indicada en el apartado 3 del artículo 26 de la Propuesta de Directiva de 2008: cuando el cumplimiento no pueda tener lugar porque es ilegal o imposible, o impondría un esfuerzo desproporcionado para el comerciante. En estos casos, el consumidor puede optar entre la rebaja del precio o la resolución del contrato, pues en ellos no ha lugar al cumplimiento.

${ }^{86}$ Para un estudio de los sistemas de remedios por falta de conformidad en el Derecho europeo e internacional de los contratos y la opción libre o restringida del comprador, véase Hanna Sivesand, The Buyer's Remedies for Non-Conforming Goods. Should there Free Choice or are Restrictions Necessary?, Munchen, Armand Colin Editeur, 2005.

${ }^{87}$ Véase Fenoy Picón (n. 84), p. 182. "En la tramitación de la Directiva 1999/44 se percibe que, descubierta la falta de conformidad, el legislador comunitario ha procedido a una valoración ponderada de los intereses de vendedor y comprador. En la versión definitiva de la Directiva, primero se va a intentar salvar la eficacia del contrato, lo que claramente protege al vendedor, aunque al mismo tiempo se protege al consumidor en cuanto que puede conseguir aquello que contrató. Pero si el intento de cumplimiento no tiene éxito, o no era posible hacerlo, o causaba graves inconvenientes para el consumidor, entonces se abre para este último la posibilidad de la resolución del contrato”. 
En la Exposición de motivos de la Propuesta de modernización se explica que se establece un sistema que generaliza la figura del incumplimiento, pero en el que su dibujo no es el mismo en cada uno de los remedios. Y en la Exposición de motivos de la Propuesta de compraventa se expresa:

“conforme al nuevo sistema, la falta de ejecución de cualquier obligación resultante del contrato constituye incumplimiento con independencia de que la inejecución sea imputable o no al deudor. Y el incumplimiento da lugar a la aplicación de un sistema articulado de remedios, que puede poner en juego el acreedor; sistema integrado por la pretensión de cumplimiento, la reducción del precio, la resolución y la indemnización de daños".

Y agrega:

"básicamente el nuevo sistema se caracteriza por utilizar un concepto unitario de incumplimiento del contrato y articular, adecuadamente, los remedios tradicionales con que cuenta el acreedor" 88 .

El artículo 1190 de la Propuesta de modernización reconoce al acreedor la facultad de elegir, conforme a las reglas del capítulo VII, entre varios remedios:

- el derecho de exigir el cumplimiento,

- la reducción del precio y

- la resolución del contrato, en cualquier caso con la posibilidad de solicitar, además,

- la indemnización de los daños producidos.

Asimismo, el artículo 1191 le confiere al acreedor de un contrato bilateral -que será la regla en el tráfico- la facultad de suspender la realización de su propia obligación, total o parcialmente, hasta que la otra parte ejecute o se allane a ejecutar la contraprestación ${ }^{89}$. Por su parte, el artículo 1196, en la sección sobre la acción de cumplimiento, prevé como remedio el commodum representationis al prescribir:

${ }^{88}$ Ministerio de Justicia (n. 65), p. 109.

${ }^{89} \mathrm{La}$ facultad de suspender el propio cumplimiento se encuentra establecida a favor del acreedor, tanto en los Principios de UNIDROIT (artículo 7.3.1), como en los PECL (art. 9:201). Ambas disposiciones consideran una regla ajena a la Propuesta, pero a la que puede llegarse aplicando el mismo precepto extensivamente y considerando el modelo seguido por la Comisión de Codificación. Se establece, para el caso que las partes han de cumplir de modo sucesivo, la autorización a aquella que ha de ejecutar su obligación después a suspender su cumplimiento, hasta que el contratante que ha de hacerlo primero haya cumplido. 


\begin{abstract}
"si resultare imposible la obligación de dar una cosa determinada, corresponderán al acreedor las acciones que el deudor tuviere contra terceros en razón de ésta -y agrega- si las ejercitare, de la indemnización de daños y perjuicios que le pudiera corresponder se deducirá el valor de lo percibido".
\end{abstract}

Sin perjuicio de lo que se dirá a propósito de la indemnización de daños, el nuevo sistema reconoce la libre opción al acreedor afectado, lo que contrasta con el sistema previsto en la Propuesta de compraventa que, siguiendo el modelo de la directiva 1999/44, organiza jerárquicamente los remedios a la falta de conformidad, constriñendo al comprador a insistir en el cumplimiento -reparación o sustitución- y sólo si esto no es posible o desproporcionado, o el vendedor no cumple, procede el ejercicio opcional de los otros remedios. Así, en la Exposición de Motivos se expresa:

"Entre los remedios por falta de conformidad enumerados en el nuevo artículo 1482 existe jerarquía, tal como sucede en la Directiva. Primero, ha de ejercitarse la pretensión de cumplimiento; subsidiariamente, la reducción del precio o la resolución. La indemnización no plantea problema alguno de jerarquía, por ser compatible con todos ellos. La jerarquía no está expresamente formulada, pero resulta del nuevo artículo 1485, en el que se limita al comprador el ejercicio de la facultad de resolver el contrato o de exigir la reducción del precio. La razón de la jerarquización de los remedios está en el intento de conservar el contrato en sus términos iniciales y dar al vendedor la oportunidad de subsanar su inicial incumplimiento" 90 .

Un sistema como el de la Propuesta de compraventa, como se explicó, no sólo privilegia la conservación del negocio, también, y sobre todo, la satisfacción del interés del acreedor.

A diferencia de la Convención de Viena, los Principios UNIDROIT y los PECL, en la Propuesta de modernización aparentemente la indemnización de daños y perjuicios sólo procedería como complementario de los otros, no pudiendo el acreedor demandar de manera directa y exclusiva la indemnización del importe de la prestación o su menor valor por la falta de conformidad, más otros daños subsecuentes.

Y digo aparentemente, porque, si bien el artículo 1190 declara el carácter complementario de la indemnización de daños, después se reconocen supuestos en los que el acreedor estaría autorizado para demandar directa

\footnotetext{
${ }^{90}$ Ministerio de Justicia (n. 65), p. 114.
} 
y exclusivamente, el menor valor de la prestación o su cuantía total. Así, el artículo 1198 que regula la relación interna entre el derecho a reducir el precio y la indemnización de daños, declara que aquél es incompatible con la indemnización por la disminución del valor de la prestación, no obstante su derecho al resarcimiento de cualquier otro perjuicio que haya podido sufrir.

El precepto está reconociendo que el acreedor tiene la opción entre la reducción del precio y la indemnización del menor valor de la prestación no conforme. Lo mismo acontece en el citado artículo 1196 que, de igual modo, confiere al acreedor, en caso de imposibilidad de cumplimiento de una obligación de dar una cosa determinada, la opción entre el ejercicio de las acciones que el deudor tuviere contra terceros y la indemnización de daños por el valor de la cosa, pudiendo, incluso, ejercitarlos en forma conjunta.

Hay poca claridad sobre el punto y hace falta corregirlo, precisando el contenido de la indemnización de daños, en orden a si ella comprende plenamente el interés en la obtención de la prestación, incluso, su valor, o no lo considera, para luego determinar la relación existente entre este remedio y los restantes.

De la interpretación de los preceptos citados, fluye que la indemnización actúa, por regla general, como complemento de los otros remedios; sin embargo, habrían casos en los que procedería su ejercicio exclusivo sin mediar la resolución del contrato. De este modo, tratándose de la falta de cumplimiento si la prestación fuere imposible de ejecutar, el acreedor podría acceder a la indemnización o a la cesión de acciones contra terceros, sin resolver el contrato, salvo que así lo desee. En cambio, en materia de cumplimientos no conformes con el contrato, la regla parece ser diversa: el acreedor sí puede optar entre cualquiera de los remedios y la indemnización plena: menor valor más otros perjuicios indemnizables, según el artículo 1208 de la Propuesta.

Dentro de otro orden de cosas, llama la atención que la Propuesta no reconoce, como sí lo hacen la Convención de Viena ${ }^{91}$, los Principios de UNIDROIT y los PECL ${ }^{92}$, el derecho del deudor a subsanar el incumplimiento.

Dicha subsanación puede ser considerada desde dos perspectivas: la primera, desde el derecho del deudor a corregir o subsanar su cumplimiento imperfecto o no conforme y la segunda, desde los efectos que produce la concesión por el acreedor de un plazo adicional para la ejecución ${ }^{93}$.

\footnotetext{
${ }^{91}$ Convención de Viena, artículo 37.

${ }^{92}$ PECL, artículo 8.104.

${ }_{93}$ Así lo reconocen Diez-Picazo, Roca Trías, Morales Moreno (n. 3), pp. 327-328.
} 
Así, el artículo 7.1.4 de los Principios de UNIDROIT dispone que la parte incumplidora puede subsanar a su cargo cualquier incumplimiento, siempre que concurran las condiciones que el precepto fija, entre las cuales se cuenta que el acreedor carezca de interés legítimo en rechazar el ofrecimiento de subsanación.

El efecto de la subsanación es el de suspender el ejercicio de cualquier derecho del acreedor que sea incompatible con ella, sin privarle, en todo caso, de la indemnización de daños por la inejecución. Como se expresa en los Comentarios del precepto, el derecho a subsanación favorece la conservación del contrato y es una manifestación del principio de la minimización del daño y de la buena fe negocial ${ }^{94}$.

Surge la interrogante sobre cuál sería la conducta que debiese observar el acreedor frente a la oferta de subsanación de la falta de conformidad, según el régimen legal del incumplimiento de la Propuesta de modernización.

Una negativa injustificada del acreedor podría, según sean las circunstancias del caso y de acuerdo con las exigencias de la buena fe objetiva, considerarse una omisión de la carga de mitigar las pérdidas, impuesta por el artículo 1211, produciendo la reducción de la indemnización de daños. Desde luego, si el acreedor acepta la subsanación deberá conceder un plazo adicional, sin perjuicio de su derecho a la indemnización de los daños que 276 provoque el incumplimiento.

¿Cuáles son los remedios al incumplimiento contractual que la Propuesta reconoce al acreedor?

La Propuesta regula en distintas secciones de su capítulo vir los remedios particulares de que dispone el acreedor, sus condiciones, efectos y la relación interna generada entre ellos.

(A) La acción de cumplimiento (sección segunda, capítulo vII, artículos 1192 a 1196) ${ }^{95}$

La propuesta es fiel a la tradición del Derecho Civil continental al reconocer al acreedor el derecho a exigir el cumplimiento conforme al contrato, como manifestación del principio de su fuerza obligatoria. En efecto, la sección

${ }^{94}$ UNIDROIT, Instituto InTERnacional PARA La Unificación DEl Derecho Privado “Comentario No 1 del artículo 7.1.4" (n. 2), p. 204.

${ }^{95}$ Para un estudio de la pretensión de cumplimiento específico en casos de falta de conformidad, recogiendo el influjo de la Convención de Viena y de los Principios de UNIDROIT y los PECL, véase Antonio Manuel Morales Moreno, "La pretensión de cumplimiento y pretensión indemnizatoria", en Antonio Manuel Morales Moreno, La modernización del derecho de obligaciones, Navarra, Civitas, 2006 pp. 55-92 y Antonio Manuel Morales Moreno, "El derecho a la reparación o sustitución de la cosa no conforme y la naturaleza de la obligación del vendedor", en Antonio Manuel Morales Moreno, La modernización del derecho de obligaciones, Navarra, Civitas, 2006 pp. 189-202. 
segunda del capítulo viI, en lo relativo a la acción de cumplimiento, recoge en su artículo 1192 el derecho a reclamar la ejecución de la prestación. Y la expresión "exigir el cumplimiento" comprende tanto el requerimiento extrajudicial que hace el acreedor como la demanda judicial de cumplimiento en contra del deudor.

El citado precepto distingue las obligaciones dinerarias de aquellas distintas a las de pagar una suma de dinero, sean de dar -una cosa determinada o genérica-, de hacer y no hacer. En las primeras se trata de un derecho de carácter absoluto ("el acreedor [...] tiene, en todo caso, el derecho a exigir el cumplimiento"), no así en las segundas, al someter la procedencia del remedio a restricciones.

Tratándose de obligaciones no dinerarias, la pretensión de cumplimiento opera tanto en hipótesis de no cumplimiento como en aquéllas de cumplimiento no conforme al contrato, en cuyo caso asume la modalidad de reparación o rectificación y sustitución de la prestación defectuosa ${ }^{96}$. Como sea, la procedencia de la acción de cumplimiento específico, en esta clase de obligaciones, queda limitada cuando:

1) la prestación sea jurídica o físicamente imposible;

2) el cumplimiento o la ejecución forzada, resulten excesivamente onerosos;

3) la pretensión de cumplimiento sea contraria a la buena fe y

4) la prestación sea personal del deudor ${ }^{97}$.

${ }^{96}$ El artículo 1193 prescribe: "El derecho del acreedor al cumplimiento comprende, con las mismas limitaciones establecidas en el artículo anterior, la reparación o rectificación de los defectos de la prestación ejecutada o su sustitución por otra conforme a lo pactado cuando la naturaleza de la obligación no lo impida”. La propuesta sigue el modelo de la Convención de Viena (artículo 46), el de los Principios de UNIDROIT (artículo 7.2.3) y el de la directiva 1999/44, reconociendo el derecho del acreedor a exigir, o la reparación o la sustitución de la prestación no conforme. Los PECL, en cambio, se limitan a conferir al acreedor, genéricamente, el derecho a corregir o subsanar el cumplimento defectuoso (artículo 9:102). Estas modalidades de la pretensión de cumplimiento están sometidas a las mismas restricciones aplicables a supuestos de falta de cumplimiento. Sin embargo, llama la atención que para la sustitución la única limitación es la naturaleza de la prestación, como en el caso de las cosas determinadas. Se echa en falta la limitación prevista por el artículo 46 de la Convención de Viena, en orden a que el incumplimiento deba ser esencial para la resolución del contrato. No obstante, de mantenerse el texto, los esfuerzos deberán orientarse a aplicar el límite del numeral 3 del artículo 1192, por estimarse contraria a la buena fe la pretensión de sustitución de la prestación en casos de incumplimientos no esenciales.

${ }^{97}$ La Convención de Viena reconoce al comprador, en general, el derecho al cumplimiento de la obligación de entrega conforme al contrato (artículos 45, letra a) y 46 [1]), previendo limitaciones sólo para la falta de conformidad. La reparación debe ser razonable conforme las circunstancias (artículo 46 [3]) y la sustitución requiere de un incumplimiento esencial (artículo 46 [2]). En ambos casos, el comprador debe reclamar el cumplimiento al vendedor dentro de un plazo razonable. 
Si bien la Propuesta sigue el modelo de los Principios UNIDROIT (artículo 7.2.2) y los PECL (art. 9:102), omite considerar, entre los límites, aquél que consiste en que el acreedor pueda obtener la prestación o la satisfacción de su interés por otra vía; y otro de carácter temporal, al fijar un plazo de duración razonable para el ejercicio extrajudicial de este remedio ${ }^{98}$. En todo caso, si el acreedor insiste en el cumplimiento específico siendo razonable para la satisfacción de su interés resolver el contrato y celebrar una operación de reemplazo o demandar la indemnización de daños y la pretensión de cumplimiento específico incrementa las pérdidas, el deudor, pese a quedar obligado a la ejecución podrá invocar la infracción de la carga de mitigar las pérdidas y solicitar la reducción de la indemnización ex artículo 1208. Y, tratándose de una petición intempestiva, podría invocar el límite general del No 3 del párrafo segundo del artículo 1192.

Sobre los límites a la pretensión de cumplimiento específico conviene hacer algunas precisiones.

a) La imposibilidad podrá ser jurídica o física $\left(\mathrm{N}^{\mathrm{O}} 1\right)$. Si ella es sobrevenida, como en el caso de la destrucción de la cosa específica o de la prohibición de comercialización de un determinado bien o de la restricción en la prestación de un servicio, el acreedor no puede exigir el cumplimiento, pero sí ejercitar alguno de los otros remedios, como la resolución o la indemnización de daños y, si procede, impetrar las acciones del deudor contra terceros cuando el objeto de la obligación sea una cosa determinada (artículo 1196). Si la imposibilidad es originaria, la propuesta no sólo sitúa el problema en la validez del contrato sino que, también, lo ubica en la línea del incumplimiento al haberse generado la confianza en el acreedor, autorizándolo, en consecuencia, para ejercitar los restantes remedios.

b) La excesiva onerosidad del cumplimiento o, en su caso, de la ejecución forzada ( $\left.\mathrm{N}^{\mathrm{O}} 2\right)$. El supuesto, pese a la terminología empleada en la Propuesta, no necesariamente coincidirá con aquél de la alteración extraordinaria de las circunstancias básicas del contrato (artículo 1213), al requerir éste la concurrencia de condiciones más

${ }^{98}$ En los comentarios al artículo 7.2.2. se expresa: "El cumplimiento de un contrato frecuentemente requiere de una preparación especial y del esfuerzo del deudor. Si llega el momento del cumplimiento, pero el acreedor no lo reclama dentro de un plazo razonable, el deudor está facultado para presumir que el acreedor ya no insistirá en el cumplimiento específico. Si al acreedor se le permitiera dejar al deudor en estado de incertidumbre acerca del momento en que el cumplimiento específico podría ser reclamado, se corre el riesgo de que el acreedor especule en forma desleal, en detrimento del deudor y de un sano desarrollo del mercado". UNIDROIT, Instituto Internacional para la Unificación DEL Derecho Privado Comentarios artículo 7.2.2. de los Principios UNIDROIT (n. 2), p. 221. 
$\operatorname{estrictas}^{99}$. De esta forma, el último precepto prevalecerá sobre la regla que limita la procedencia del cumplimiento específico, autorizando al acreedor el recurso a los restantes remedios ${ }^{100}$. En los PECL se plantea la cuestión y en los comentarios se sostiene la prevalencia, por especialidad, de la modificación y posible resolución del contrato, sobre la limitación al cumplimiento específico y la apertura a los restantes remedios ${ }^{101}$. La lectura que debe hacerse de este límite es que la señalada pretensión no implique costos ni sacrificios no razonables para el deudor, en términos que, si bien es aún posible, es tan costoso para este último que reclamarlo atentaría contra el principio general de la buena fe y la lealtad negocial ${ }^{102}$.

c) La prestación personal del deudor $\left(\mathrm{N}^{\circ} 4\right)$. En casos como éstos la ejecución forzada podría afectar la libertad individual del deudor y, muy probablemente, se alteraría la calidad de la prestación ${ }^{103}$. Debe tratarse de una obligación indelegable atendida la propia característica del servicio y las destrezas o habilidades del deudor o la especial relación con el acreedor ${ }^{104}$. No queda comprendida aquella

99 "Si las circunstancias que sirvieron de base del contrato hubieren cambiado de forma extraordinaria durante su ejecución de manera que ésta se haya hecho excesivamente onerosa para una de las partes o se haya frustrado el fin del contrato, el contratante al que, atendidas las circunstancias del caso y especialmente la distribución contractual o legal de riesgos, no le sea razonablemente exigible que permanezca sujeto al contrato, podrá pretender su revisión, y si ésta no es posible o no puede imponerse a una de las partes, podrá aquél pedir su resolución. La pretensión de resolución solo podrá ser estimada cuando no quepa obtener que la propuesta o propuestas de revisión ofrecidas por cada una de las partes una solución que restaure la reciprocidad de intereses del contrato".

${ }^{100}$ Para un análisis del artículo 1213 de la Propuesta de modernización y su posible vinculación con el incumplimiento del contrato y los remedios del acreedor, véase Pablo Salvador Coderch, "Alteración de circunstancias en el art. 1213 de la Propuesta de Modernización del Código Civil en materia de Obligaciones y Contratos", en Indret, $\mathrm{N}^{\mathrm{O}}$ 2, 2009, disponible en http://www.indret.com/pdf/687_es.pdf, visitado el 14 de febrero de 2011.

101 The Commission on European Contract Law, Lando, Beale (eds.), "Comment", (n. 3), p. 396.

102 Cfr. Unidroit, Instituto Internacional para la Unificación del Derecho Privado, Comentarios al artículo 7.2.2., (b) de los Principios UNIDROIT (n. 2), p. 219. En ellos se ofrece un ejemplo: “1. Un buque petrolero naufraga en aguas costeras durante una fuerte tempestad. Aunque sería posible recuperar el buque desde el fondo del mar, el cargador no podría reclamar el cumplimiento del contrato de transporte si esto fuese a ocasionar al naviero gastos muy por encima del valor del petróleo".

${ }^{103} \mathrm{Cfr}$. Comentarios al artículo 7.2.2, UNIDROIT, InstituTo INTERNACIONAL PARA LA Unificación del Derecho Privado (n. 2), p. 220.

${ }^{104}$ En los comentarios de los Principios UNIDROIT, se expresa que cumplimiento será exclusivamente de naturaleza personal cuando no sea objeto de delegación y exija la destreza particular de naturaleza artística o científica, o si implica una relación confidencial 
obligación de hacer, consistente en una declaración de voluntad del deudor; para este supuesto, el artículo 1195 de la Propuesta confiere al acreedor el derecho a obtener el cumplimiento según la norma procesal civil, pero si se hubiere pactado una pena para el incumplimiento sólo podrá requerir ésta, a menos que las partes hubieren convenido lo contrario.

El artículo 1194 confiere al acreedor la facultad de variar su pretensión de cumplimiento por alguno de los remedios que le reconoce el Código Civil cuando lo hubiese exigido sin obtener la satisfacción de su derecho, en forma oportuna autorizándolo para desistir del referido remedio y ejercitar otro cualquiera. La misma atribución se reconoce en los Principios UNIDROIT en su artículo 7.2.5, cubriendo un supuesto distinto, que refiere a aquel caso en que no sea factible la ejecución de un mandato judicial que ordene el cumplimiento de una obligación no dineraria, concediendo a la parte perjudicada el derecho a recurrir a otro remedio. A diferencia de UNIDROIT, la Propuesta otorga la posibilidad de variar la pretensión cuando el acreedor que exige el cumplimiento no obtuviere "

" la satisfacción de su derecho, sin hacer referencia a plazo alguno, dejando al deudor en una posición de incertidumbre, la cual aumenta en aquellos casos en que el deudor está dispuesto a cumplir y se encuentra 280 preparando la ejecución de la prestación. El artículo 7.2.5 autoriza el cambio de pretensión cuando el deudor no ejecute la obligación dentro de un plazo razonable o del plazo pactado ${ }^{105}$.

y personal. Se ofrece un ejemplo. "3. La obligación por parte de una firma de arquitectos para diseñar un conjunto de diez viviendas puede ser de cumplimiento específico en la medida en que la firma pueda delegar la tarea en uno de sus socios o bien emplear a un arquitecto externo para realizarla. 4. Por el contrario, si se le encarga a un famoso arquitecto que diseñe un nuevo conjunto residencial realizando la idea de una cuidad para el siglo XXI, no se podría encargar su ejecución forzada, ya que la prestación es única y requiere del empleo de una pericia muy especial". UNIDROIT, InSTITUTO INTERNACIONAL PARA LA Unificación del Derecho Privado, "Comentarios artículo 7.2.2, Principios UNIDROIT", (n. 2), p. 221. En la misma dirección, The Commission on European Contract Law, Lando, Beale (eds.), "Comment Article" 9:102, PECL, (n. 3), p. 397. Se ofrece el siguiente ejemplo: "Ilustración 5: A, un famoso artista, contrata con $\mathrm{B}$, un comerciante muy rico, la pintura de un cuadro para él. Si A no cumple con su obligación, B no puede requerir el cumplimiento porque la obligación de A es de destrezas artísticas y, por ende, consiste en un trabajo de una naturaleza personal".

${ }^{105}$ En los Comentarios al artículo 7.2.5 se lee: "El cambio voluntario de remedio puede permitirse si los intereses de la parte incumplidora quedan adecuadamente protegidos, ya que ésta podría haberse estado preparando para el cumplimiento o haber incurrido en gastos a tal efecto". UNIDROIT, Instituto Internacional PARA la Unificación del Derecho Privado, "Comentarios artículo 7.2.5. de los Principios UNIDROIT" (n. 2), p. 226. 
(B) La reducción del precio (sección tercera, artículos 1197 y 1198)

La Propuesta de modernización, al igual que la Convención de Viena y los PECL, generaliza el derecho del acreedor a reducir el precio cuando la prestación no se conforme con el contrato, extendiendo el remedio más allá de los vicios redhibitorios de la cosa objeto de la compraventa. La Propuesta reproduce el artículo 9:401 de los PECL, aunque con una diferencia ${ }^{106}$, desviándose de la norma que sirve de modelo a este último, la de artículo 50 de la Convención de Viena ${ }^{107}$.

En efecto, el artículo 1197 reconoce al acreedor el derecho a aceptar la prestación no conforme al contrato, a cambio de una reducción proporcional del precio según la diferencia entre el valor que tenía la obligación en el momento en que se realizó y el que hubiere tenido, en ese mismo instante, de haber sido ajustada a lo estipulado. La reducción del precio permite al acreedor obtener una compensación por el menor valor de la prestación a causa de la falta de conformidad, logrando así la satisfacción de su interés. El principio que subyace en la reducción del precio es que el acreedor conserva la prestación no conforme con el contrato y éste, a su vez, se ajusta o adapta a la nueva situación: el precio es reducido, pues la prestación tendrá un menor valor como consecuencia de la falta de conformidad, lo cual debe reflejarse en el precio.

Este remedio no constituye ni indemnización de daños ni resolución parcial del contrato, sino que consiste en una adaptación o ajuste del convenio, habida consideración la nueva realidad: la prestación no conforme al contrato, que el acreedor decide conservar ${ }^{108}$. No quiere decir que no haya incumplimiento, lo hay, y la reducción del precio es el remedio al mismo, el cual es compatible con la indemnización de daños distintos al menor valor de la prestación por la falta de conformidad, a diferencia de lo que sucede con la resolución y el cumplimiento específico, que incluye la reparación o sustitución.

${ }^{106} \mathrm{Al}$ fijar un límite temporal para el ejercicio del remedio.

${ }^{107}$ Para un estudio comparativo entre los artículos 50 de la Convención de Viena y el 9:401 de los PECL, véase Jarno VANTO, Commentary on the manner in which the Principles of European Contract Law may be used to interpret or sumplement Article 50 of the CISG, disponible en internet en http://cisgw3.law.pace/cisg/text/anno-art-50.html, visitado el 14 de febrero de 2011.

${ }_{108}$ Para la Convención de Viena, Peter Schlechtriem, "Uniform Sales Law. The UN-Convention on Contracts for the International Sales of Goods", in Law and Economics International Trade, N 9, Viena, 1989, par. 203; Markus Muller-CheN, "Article 50", in Peter Schlechtriem and Ingeborg Schwenzer (eds.), Commentary on the UN Convention on the International Sale of Goods (CISG), Second (English) Edition, Oxford, University Press, New York, 2005, par. 1, pp. 596-597. 
Cabe destacar que la relevancia para el acreedor de la reducción del precio reside en dos aspectos:

- Primero, si el acreedor aún no ha pagado el precio, le está permitido una modificación unilateral del contrato, trasladándose la carga de accionar al deudor que, si no está de acuerdo, sea con la ocurrencia del incumplimiento, sea con el monto de la reducción, acudirá al juez para que así lo declare. En esta hipótesis el remedio se ejercita extrajudicialmente, sin perjuicio de que más tarde el acreedor demande la indemnización de daños como complemento. En cambio, si el precio ha sido solucionado, la Propuesta confiere al acreedor el derecho a exigir el reembolso de lo pagado en exceso, debiendo demandar al deudor incumplidor y así declararlo el juez.

- Segundo, como no se trata de una indemnización de daños, la reducción del precio prescinde de la imputación subjetiva del incumplimiento al deudor, de modo que, aun cuando éste se encuentre exonerado de responsabilidad por un impedimento ajeno a su control, el acreedor también podrá reducir el precio ${ }^{109}$.

La reducción del precio puede ejercitarse extrajudicialmente; en caso de que el acreedor lo haga valer en sede judicial o arbitral podrá ejercitarlo como acción, pidiendo el reembolso del exceso o, bien, como excepción contra la demanda de cobro del precio por la otra parte ${ }^{110}$.

La fórmula del artículo 1197 para la rebaja de precio ${ }^{111}$ coincide con la del artículo 50 de la Convención de Viena y la del artículo 9:401 de los PECL. El citado precepto dispone:

"La parte que hubiere recibido una prestación no conforme con el contrato, podrá aceptarla y reducir el precio en proporción a la diferencia entre el valor que la prestación tenía en el momento que se realizó y el que habría tenido en ese mismo momento si hubiere sido conforme al contrato".

${ }^{109}$ Cfr. Hans Stoll - Georg Gruber, "Article 79. Commentary on the UN Convention on the International Sale of Goods (CISG)", in Peter SCHLEchtriem and Ingeborg Schwenzer (eds.), Second (English) Edition, Oxford, University Press, New York, 2005, par. 39, pp. 328329; Ángel López López, "Artículo 48-50”, en Luis Díez-PicAzo (director), La compraventa internacional de mercaderías. Comentarios a la Convención de Viena, Navarra, Civitas, 1998, p. 446; The Commission on European Contract Law, Lando, Beale (eds.), "Comment article” 9:401 PECL (n. 3), p. 431.

${ }^{110}$ Muller-Chen, Commentary (n. 108), par. 16, p. 604.

${ }^{111}$ El mismo que recoge el artículo 1487 de la Propuesta de compraventa. "La reducción del precio será proporcional a la diferencia entre el valor que la cosa entregada tenía en el momento de la entrega y el que habría tenido en ese momento si hubiere sido conforme al contrato". 
El método de la reducción que adopta la Propuesta es el relativo: el precio -fruto del acuerdo de las partes- se ajusta según la diferencia objetiva entre el valor real de la prestación imperfecta al momento de su ejecución y el valor hipotético de haber sido ésta conforme al contrato. La rebaja se produce en proporción a la diferencia de valores. La fórmula reconoce al contrato como negocio, desde que evidencia, por un lado, que el precio de la prestación no necesariamente coincide con su valor al momento de la celebración del contrato y, por otro, que dicho valor queda sujeto a fluctuaciones desde ese instante, las que no repercuten en términos absolutos en el precio, sino proporcionalmente, si el comprador decide conservar la prestación no conforme, reduciendo el precio. Se permite, de esta forma, mantener la proporción entre el precio del contrato y el objetivo valor de las mercaderías ${ }^{112}$.

La fórmula de cálculo del precio reducido es la que sigue:

Precio Reducido $(\mathrm{PR})=$ valor de la prestación realizada no conforme al contrato $(\mathrm{VPR})$ * Precio de contrato $(\mathrm{PC})$

valor hipotético de la prestación conforme (VHPC)

El artículo 1198 de la Propuesta zanja la relación entre la reducción del precio y la indemnización de daños, al declarar incompatible la rebaja con la indemnización por el menor valor de la prestación defectuosa, no así con la de otros daños distintos, reparables según las reglas generales. Así sucedería, por ejemplo, en el caso de la entrega no conforme de una construcción, en el acreedor no puede vivir en ella en razón de los defectos de que adolece, viéndose obligado a arrendar otro inmueble por un mes. $\mathrm{El}$ acreedor reduce el precio proporcionalmente, encarga la reparación a un tercero y experimenta daños, en concreto, los gastos en que incurre con el pago de la renta por el arrendamiento del mes que tardaron las reparaciones. He aquí un caso en el que el acreedor junto con reducir el precio del contrato, demanda la indemnización de daños diversos al menor valor de la prestación a causa de la falta de conformidad ${ }^{113}$.

A diferencia de lo que sucede en la Convención de Viena y en los PECL, la Propuesta somete el ejercicio de este remedio a un plazo de caducidad de

${ }^{112}$ Para la Convención de Viena, Michael Will afirma que el artículo 50 en vez de adoptar un método absoluto, se inclina por uno relativo, que permite seguir en la línea con su buen o mal negocio, al mantener la proporción entre el precio del contrato y el valor objetivo de las mercaderías. Michael WiLL, "Article 50", in Cesare Massimo BiAnCA y Michael Joachim Boneld, Commentary on the International Sales Law, The Vienna Sales Convention, Milan, Giuffrè, 1987, p. 370.

${ }^{113}$ Cfr. The Commission on European Contract Law, Lando, Beale (eds.), "Comment article" 9:401, "Ilustration" 4 (n. 3), p. 431 
seis meses desde que se hubiere recibido la prestación. Llama la atención la falta de armonía entre la solución de la Propuesta de modernización y la que da la Propuesta de compraventa, que no establece un plazo de caducidad para pedir la reducción del precio, sino que se limita a fijar un término de prescripción de dos años ${ }^{114}$.

Los problemas que podría plantear el ejercicio de este remedio al incumplimiento contractual y que no resuelve la Propuesta, son, a mi juicio, dos:

a) la forma en que se hace la declaración cuando el acreedor reduce el precio unilateral y extrajudicialmente y si debe indicar o no la suma o el importe de la rebaja. En materia de compraventa internacional se sostiene que la comunicación puede hacerse de cualquier forma, a condición de que la intención de reducir el precio del contrato sea lo suficientemente clara, atendida la falta de conformidad denunciada conforme al artículo 39 de la Convención de Viena; y también se señala que no es indispensable fijar en ella el monto de la rebaja, aunque por lo general sí se especifica. El riesgo de una declaración ambigua de reducción es que pueda estimarse como una retención de parte del precio y, en definitiva, el acreedor aparezca incumpliendo su obligación en el contrato ${ }^{115}$.

b) la carga de la prueba corresponde al acreedor; será éste quien junto con probar la falta de conformidad, deberá acreditar el valor real de la prestación no conforme y rendir la prueba sobre el valor hipotético, es decir, el que habría tenido de haber sido conforme el contrato.

(C) La resolución por incumplimiento (sección cuarta, artículos 1199 a 1204)

La resolución se sitúa entre los remedios frente al incumplimiento y se la concibe como una facultad del acreedor para obtener la satisfacción de su interés. En la Propuesta, la resolución prescinde de la imputación subjetiva del incumplimiento, en términos que ella procede con independencia de si la inobservancia es o no excusable, conforme a su artículo 1209. A lo anterior, se añade la modificación a la regla de la transmisión del riesgo casual de pérdida y deterioro al comprador, que en la Propuesta se produce desde el momento que el vendedor ha realizado todo aquello que le incumbe según el contrato (artículo 1452). Claramente la Propuesta en esta materia sigue el modelo de la Convención de Viena, de los Principios UNIDROIT y los PECL ${ }^{116}$.

${ }^{114}$ Véase artículo 1488, No 2 que fija plazo de prescripción de dos años para los derechos $\mathrm{y}$ acciones que corresponden al comprador por falta de conformidad de la cosa.

${ }^{115}$ Muller-Chen, “Commentary” (n. 108), par. 4, p. 598.

${ }^{116}$ Cfr. Lis Paula San Miguel Pradera, "La modernización del Derecho de obligaciones y la resolución por incumplimiento en los ordenamientos español y chileno", Iñigo DE LA 
Siguiendo la tendencia de adoptar el modelo de resolución por declaración unilateral ${ }^{117}$, la propuesta prevé una resolución extrajudicial que opera por comunicación a la otra parte, haciendo abandono de la misma en sede judicial ${ }^{118}$. Además, se requiere para su procedencia, por regla general, de un incumplimiento esencial del contrato.

En efecto, la resolución interviene cuando, atendida la finalidad del contrato, el incumplimiento es esencial (artículo 1199). A diferencia de los ordenamientos de referencia, en la Propuesta no se define el incumplimiento esencial, como sucede, por ejemplo, en la Convención de Viena (artículo 25), ni tampoco ofrece criterios legales para determinar cuándo la inejecución reúne las características para ser considerada o no como tal, como sí lo hacen los Principios UNIDROIT (artículo 7.3.1) y los PECL (artículos 9:301 en relación con el 8:103).

Los artículos 49 y 64 de la Convención de Viena junto con reconocer la facultad de resolver el contrato, exigen para su procedencia un incumplimiento esencial y el artículo 25 lo define como aquél que:

"cause a la otra parte un perjuicio tal que la prive sustancialmente de lo que tenía derecho a esperar en virtud del contrato, salvo que la parte que haya incumplido no hubiera previsto tal resultado y que una persona razonable de la misma condición no lo hubiera previsto en igual situación".

Cualquiera sea la modalidad de incumplimiento, sea del vendedor o del comprador, dos son los requisitos de necesaria concurrencia:

(a) debe privar sustancialmente al acreedor de lo que tenía derecho a esperar en virtud del contrato y

(b) dicho resultado debe resultar previsible para el deudor al momento de la celebración del contrato ${ }^{119}$.

Maza Gazmuri (coord.), "Modernización del derecho de las obligaciones", en Cuadernos de Análisis Jurídico, Santiago, Ediciones de la Universidad Diego Portales, Colección Derecho Privado vol. vi (en prensa).

${ }^{117}$ En el moderno Derecho de Contratos prevalece la resolución por comunicación del acreedor. Así, el artículo 26 de la Convención de Viena declara: "la declaración de resolución del contrato surtirá efecto sólo si se comunica a la otra parte”. Por su parte, el artículo 7.3.2 (1) de los Principios UNIDROIT prescribe: "el derecho de una parte a dar por terminado el contrato se ejercitará mediante comunicación a la otra parte”. Lo mismo ocurre en los PECL, pues su artículo 9:303 (1) así lo declara.

${ }^{118}$ Pareciera que la Propuesta de modernización no descarta del todo la posibilidad de resolución judicial; el artículo 1202, en materia de efectos de la resolución, alude a la acción resolutoria.

${ }^{119}$ En la discusión del precepto no hubo acuerdo acerca del momento en el cual el deudor debía prever tal resultado. John Honnold, Uniform Law for International Sales under 
Siguiendo a la Convención de Viena, los Principios de UNIDROIT también exigen para la resolución que el incumplimiento sea esencial (artículo 7.3.1 [1] $)^{120}$, sin embargo, establece un elenco de criterios para definir cuándo la inejecución reviste tal carácter (artículos 7.3.1 [2]) ${ }^{121}$. Los PECL se sitúan en la misma dirección, requiriendo para la resolución un incumplimiento esencial (artículo 9:301 [1] ${ }^{122}$; no obstante, a diferencia de los Principios de UNIDROIT, los criterios para determinar la calidad de esencial no están en la sección referida a la resolución, sino en los artículos generales del capítulo sobre incumplimiento y remedios del acreedor, en concreto, en el artículo 8:103 ${ }^{123}$. Según la norma, se entenderá que se está en presencia de un incumplimiento esencial, si se presenta una de las tres hipótesis previstas y que coinciden con aquellas de los Principios de UNIDROIT, aunque simplificadas. De acuerdo con la primera de ellas, habrá una inejecución de la envergadura señalada si la observancia estricta de la obligación infringida forma parte de la esencia del contrato. La segunda, si se trata de un incumplimiento que prive sustancialmente a la parte perjudicada de lo que tiene derecho a esperar en virtud del contrato, a menos que la otra parte no lo haya previsto o no haya podido con razonabilidad prever tal resultado. Y la tercera, si el incumplimiento es intencionado y da a la parte lesionada motivos para creer que no puede confiar en la futura ejecución.

the 1980 United Nations Convention, The Hague, Kluwer Law International, 1999, par. 183. Sin embargo, hoy la doctrina se inclina por considerar como momento relevante el de la celebración del contrato. Así, Schlechtriem, "Uniform Sales..." (n. 108), par. 15: "if the knowledge or foreseeability is to be equivalent to express agreement, it must in any event at the time when the contract was concluded. Subsequent information may possibly lead to additions to the contracts". Schlechtriem, “Article 25" (n. 108) par. 15, pp. 290-291.

${ }^{120}$ Art. 7.3 .1 (1): "Una parte puede resolver el contrato si la falta de cumplimiento de una de las obligaciones de la otra parte constituye un incumplimiento esencial".

${ }^{121}$ Art. 7.3.1. (2): "Para determinar si la falta de cumplimiento de una obligación constituye un incumplimiento esencial se tendrá en cuenta, en particular, si: (a) el incumplimiento priva sustancialmente a la parte perjudicada de lo que tenía derecho a esperar en virtud del contrato, a menos que la otra parte no hubiera previsto ni podido prever razonablemente ese resultado; (b) la ejecución estricta de la prestación insatisfecha era esencial según el contrato; (c) el incumplimiento fue intencional o temerario; (d) el incumplimiento da a la parte perjudicada razones para desconfiar de que la otra cumplirá en el futuro; (e) la resolución del contrato hará sufrir a la parte incumplidora una pérdida desproporcionada como consecuencia de su preparación o cumplimiento".

${ }^{122}$ Article 9:301 (1): "A party may terminate the contract if the other party's nonperformance is fundamental".

${ }^{123}$ Article 8:103: "A non-performance of an obligation is fundamental to the contract if: (a) strict compliance with the obligation is of the essence of the contract; or (b) the nonperformance substantially deprives the aggrieved party of what it was entitled to expect under the contract, unless the other party did not foresee and could not reasonably have foreseen that result; or (c) the non-performance is intentional and gives the aggrieved party reason to believe that it cannot rely on the other party's future performance". 
Es preferible la norma de los PECL, ella simplifica los criterios y excluye uno y con razón, el del numeral 5 del artículo 7:3.1 (2), que más que servir para definir si el incumplimiento es o no esencial, fija un límite a la procedencia del remedio resolutorio ${ }^{124}$.

La Propuesta, siguiendo el modelo de la Convención de Viena, los Principios de UNIDROIT y los PECL, también autoriza la resolución cuando, habiendo retraso en el cumplimiento o falta de conformidad, el deudor no cumple dentro del plazo razonable que le concediera el acreedor para llevar a cabo la obligación o subsanar el defecto (artículo 1200, inciso $1^{\circ}$ ).

En efecto, en la Convención de Viena también procede la resolución por el transcurso infructuoso del plazo suplementario concedido al deudor para que cumpla ${ }^{125}$. Ella exige que este término sea de duración razonable y el efecto de su concesión es que, mientras se halle pendiente, el acreedor no puede ejercitar ningún remedio, no obstante su derecho a la indemnización de daños. La regla cede cuando el deudor comunica antes del vencimiento del plazo que no cumplirá ${ }^{126}$.

Por su parte, el artículo 7.1.5 de los Principios de UNIDROIT reconoce al acreedor la facultad de conceder un plazo suplementario al deudor para que cumpla, pudiendo el acreedor suspender la ejecución de su propia prestación durante éste y reclamar la indemnización de daños, sin poder ejercitar ningún otro remedio. El párrafo tercero del artículo 7.1.5 prevé el caso del retardo en el cumplimiento que no constituya incumplimiento esencial, autorizando la resolución sólo cuando, habiéndole concedido al deudor un plazo suplementario de duración razonable, éste no cumpla. Se añade la posibilidad de que en la misma comunicación que concede el referido término, el acreedor establezca que si no se cumple dentro del mismo, el contrato se resolverá automáticamente. Y el artículo 7.1.5 (4) fija un límite para la resolución, consistente en que ella no procederá cuando la prestación incumplida represente una mínima parte de la obligación del deudor.

Finalmente, el artículo 9:301 de los PECL también autoriza la resolución para el caso de retardo según el artículo 8:106 (3). El precepto confiere al acreedor la facultad de conceder al deudor un plazo suplementario de duración razonable para cumplir. En este caso, el acreedor podrá resolver el contrato si tal plazo expira sin que el deudor cumpla ${ }^{127}$.

${ }^{124}$ Cfr. San Miguel Pradera (n. 116), p. 33.

${ }^{125}$ Véase $47 \mathrm{CV}$ que prescribe sobre el plazo suplementario otorgado por el comprador al vendedor; y el artículo $63 \mathrm{CV}$ sobre el plazo concedido por el vendedor al comprador.

${ }^{126}$ Sobre la concesión del plazo suplementario, su duración y efectos en estos ordenamientos, véase San Miguel Pradera (n. 16), pp. 462-464.

${ }^{127}$ Comentando estas dos formas de resolución, una por incumplimiento esencial y otra por el transcurso infructuoso del plazo adicional, SAN Miguel Pradera (n. 116), p. 38 justifica 
Respecto de este último supuesto, siguiendo a Lis San Miguel Pradera, dos son los vacíos que se advierten y que sería muy conveniente suplir. En primer término, debiera establecerse como límite, en los casos de incumplimientos no esenciales, la improcedencia de la resolución si la infracción contractual es de poca relevancia. Y enseguida, se echa en falta en la Propuesta una disposición sobre los efectos de la concesión del plazo suplementario al deudor para cumplir o subsanar su incumplimiento, como ocurre en la Convención de Viena, los Principios UNIDROIT y los PECL, en orden a privar al acreedor del ejercicio de cualquier remedio mientras el término se encuentre pendiente, sin perjuicio de su derecho a la indemnización de daños por el incumplimiento ${ }^{128}$.

Siguiendo el modelo de los ordenamientos de referencia, se agrega aquel supuesto según el cual el acreedor también podrá resolver cuando el deudor hubiere declarado que no llevará a cabo sus obligaciones, sin necesidad de un incumplimiento esencial ni la fijación previa de un plazo razonable (artículo 1200, inciso $3^{\circ}$ ).

Por último, se prevé la resolución por incumplimiento esencial anticipado. En efecto, el acreedor puede resolver el contrato cuando exista un riesgo evidente de incumplimiento esencial conforme al artículo 1199 y el deudor no cumpla ni preste una garantía adecuada de cumplimiento dentro del plazo de duración razonable que el acreedor le hubiere fijado al efecto. Cabe destacar que la Propuesta no distingue, como sí lo hace la Convención de Viena y los Principios de UNIDROIT, casos en que resulta patente que el deudor incurrirá en incumplimiento esencial (artículo 72 de la Convención de Viena y artículo 7.3.3, "incumplimiento anticipado", de los Principios de UNIDROIT) ${ }^{129}$, de aquéllos en que el acreedor crea o tema razonablemente que cometerá esta clase de inejecución (artículo 71 de la Convención de Viena y artículo 7.3.4 "Garantía adecuada de cumplimiento" de los Principios de UNIDROIT). En ambos cuerpos normativos, la resolución anticipada del contrato procede en forma directa respecto del primer caso, sin posibilidad de que el deudor pueda evitarla y, en el segundo, en cambio, la resolución sólo interviene si el deudor no ofrece garantías suficientes de cumplimiento.

esta segunda forma de resolución, cuando afirma: "una correcta ponderación de ambos intereses en juego lleva al establecimiento del requisito del otorgamiento al deudor de una última oportunidad para cumplir y evitar la resolución. Además, la figura de la concesión de un plazo adicional al deudor puede tener otra utilidad importante; en concreto, puede servir al acreedor para disipar dudas acerca de la procedencia del remedio resolutorio cuando no está seguro de que éste revista carácter esencial (pues nada impide al acreedor otorgar al deudor una última oportunidad de cumplir, a pesar de existir un incumplimiento esencial)".

${ }^{128}$ Cfr. San Miguel Pradera (n. 116), p. 40.

${ }^{129}$ También PECL, artículo 9:304. 
Igual que en los ordenamientos de referencia, cuando se trata de cumplimiento retardado o falta de conformidad, la comunicación de resolución del contrato queda sujeta a un límite temporal, pues el acreedor debe hacerla dentro de un plazo razonable ${ }^{130}$. El artículo 1201 de la Propuesta, dispone que si el deudor ofreciere tardíamente el cumplimiento o lo hubiere efectuado de un modo no conforme al contrato, el acreedor pierde la facultad de resolverlo, a menos que ejercite la acción en un plazo razonable desde que tuvo o debió tener conocimiento de la oferta tardía de cumplimiento o de la no conformidad del cumplimiento. Esta norma impone una carga de comunicación al acreedor y su objeto es la protección del interés del deudor, que, si bien incumplió el contrato, quiere subsanar dicho incumplimiento o asume que realizó la prestación no conforme a lo convenido.

Por otro lado, se regulan los efectos de la resolución, superando la discusión en orden a si produce o no efecto retroactivo. La resolución libera a las partes de las obligaciones contraídas en virtud del contrato, pero no afecta las estipulaciones relativas a la decisión de controversias ni a cualquiera otra que regule los derechos y obligaciones de los contratantes tras la resolución como, por ejemplo, una cláusula compromisoria o una cláusula penal.

Se declara expresamente la compatibilidad entre la resolución del contrato y la indemnización del interés positivo; y se establece una presunción de daño provocado por el incumplimiento igual a los gastos realizados y al detrimento que sufra el acreedor por las obligaciones contraídas en consideración del contrato resuelto, esto es, la indemnización por el interés negativo. La regla se asimila a la solución del Derecho inglés para corregir la tensión entre los daños a la prestación y a la confianza. Sí debe denunciarse que la Propuesta omite una regla de fijación de una indemnización mínima en la diferencia entre el precio del contrato y el de la operación de reemplazo o el precio de mercado cuando no fuere posible o razonable tal sustitución. Esta regla la contienen tanto la Convención de Viena (artículos 75 y 76), como los Principios UNIDROIT (artículos 7.4.5 y 7.4.6) y los PECL (artículos 9:506 y 9:507). Hubiese sido deseable su inclusión, ya sea en la sección sobre la resolución o en aquella de indemnización de daños. De cualquier forma, si no se incorpora una regla como ésta, nada obsta a que el juez en casos de resolución contractual fije la indemnización utilizando este criterio.

${ }^{130}$ Así, el artículo 7.3.2 (2) de los Principios de UNIDROIT prescribe: "Si la prestación ha sido ofrecida tardíamente o de otro modo no conforme con el contrato, la parte perjudicada perderá el derecho a resolver el contrato a menos que notifique su decisión a la otra parte en un período razonable después de que supo o debió saber de la oferta o de la prestación defectuosa". 
El artículo 1203 prevé el efecto restitutorio como regla respecto de las prestaciones ya realizadas y los rendimientos obtenidos de ellas. Sin embargo, puede suceder que no sea posible tal restitución, en cuyo caso procede la entrega de su valor. Se libera de la obligación restitutoria del valor de la prestación y sus resultados a la parte que resuelve el contrato, siempre y cuando acredite que la destrucción o pérdida del objeto se produjo no obstante haber empleado la debida diligencia, solución que no beneficia a la parte incumplidora.

Por último, el artículo 1204 da una regla para el efecto restitutorio de la resolución de los contratos de ejecución continuada o sucesiva, en orden a que ésta no alcanza a las obligaciones realizadas cuando entre prestaciones y contraprestaciones exista la correspondiente reciprocidad de aquél a quien restituye.

(D) La indemnización de daños (sección quinta, artículos 1205 a 1212)

Finalmente, la Propuesta prevé sobre la indemnización de daños, un modelo que sigue de cerca el paradigma tradicional del Código Civil; no obstante, introduce modificaciones importantes que vienen a resolver y zanjar toda una discusión habida tanto en la jurisprudencia como en la 290 doctrina españolas ${ }^{131}$.

El régimen que recoge la Propuesta de modernización coincide en una buena medida con aquél de los Principios de UNIDROIT (sección 4: resarcimiento, artículos 7.4.1 a 7.4.13) y los PECL (capítulo IX, sección 5, Damages and Interest, artículos 9:501 a 9:510). Aunque es del caso reconocer que, en esta materia, la Propuesta es más fiel a su propio régimen legal, con algunas correcciones que se toman de estos dos cuerpos de normas.

La Propuesta de modernización, en su artículo 1205, tal como lo anuncia el artículo 1190, reconoce al acreedor el derecho a ser resarcido de los daños y perjuicios que el incumplimiento le cause, declarando su carácter compatible con las restantes acciones que la ley concede al acreedor en caso de incumplimiento. A diferencia de los artículos 9:501 de los PECL y 7.4.1. de los Principios UNIDROIT, el artículo 1205 no precisa el supuesto del remedio, en orden a que el derecho está condicionado a que el deudor no se hallare exonerado de responsabilidad, en este caso, según el artículo 1209.

${ }^{131}$ Pantaleón Prieto (n. 13), p. 1.737 y ss. anticipa el año 1993 los cambios necesarios al régimen de la indemnización de daños siguiendo el modelo de la Convención de Viena, los Principios de UNIDROIT y los PECL, que hoy se reflejan en la Propuesta de Modernización. Recientemente, con ocasión de la indemnización del lucro cesante por incumplimiento contractual: Morales Moreno (n. 15). 
Llama la atención el artículo 9:502 de los PECL “General measure of Damages" que, en su primera parte, expresa cuál es el fin de la indemnización de daños como remedio de que dispone el acreedor, al señalar:

"El cálculo general de los daños es aquella suma que ponga a la parte perjudicada en la situación más semejante posible a la que se hubiera encontrado si el contrato hubiera sido debidamente cumplido".

El artículo 1207 refiere al contenido de la indemnización, disponiendo que comprende no sólo el valor de la pérdida que haya sufrido el acreedor sino, también, las ganancias que haya dejado de obtener. Y, a continuación, da una regla para la apreciación del lucro cesante, que consiste en atender al grado de probabilidad de conseguir la ganancia, dentro del curso normal de los hechos y las circunstancias; esto es, se explicita la exigencia de la certidumbre del daño, determinante para su indemnización, exigencia que se torna en extremo compleja tratándose de esta especie de daño.

La disposición, salvo aquella parte sobre la certidumbre del lucro cesante, coincide con las normas de los artículos 74 parte primera de la Convención de Viena ${ }^{132}$ y 7.4.2 (1) de los Principios de UNIDROIT, aunque con una comprensión más exacta del daño y del alcance de la indemnización ${ }^{133}$. Por su parte, los PECL prevén esta situación sobre el contenido de la indemnización, en la citada norma sobre el cálculo de la misma ${ }^{134}$. Respecto a la certidumbre del daño, cabe destacar que los PECL en su artículo 9:501 (2) letra (b), establecen una regla similar a la del artículo 1207, pero

132 "La indemnización de daños y perjuicios por el incumplimiento del contrato en que haya incurrido una de las partes comprenderá el valor de la pérdida sufrida y el de la ganancia dejada de obtener por la otra parte a consecuencia del incumplimiento" Convención de Viena, artículo 74, primera parte).

133 “(1) La parte perjudicada tiene derecho a la reparación integral del daño causado por el incumplimiento. Este daño comprende cualquier pérdida sufrida y cualquier ganancia de la que fue privada, teniendo en cuenta cualquier ganancia que la parte perjudicada haya obtenido al evitar gastos y daños y perjuicios". La indemnización de daños debe quedar sujeta a ciertos descuentos cuando así proceda. En los Comentarios de los Principios UNIDROIT se expresa: "La parte perjudicada no debe enriquecerse con el resarcimiento por el incumplimiento. Esta es la razón por la que el parágrafo (1) también prevé que el resarcimiento debe tomar en consideración cualquier ganancia que la parte perjudicada hubiera podido obtener por el incumplimiento, ya sea por gastos que ha evitado (v.gr. al no tener que pagar el costo del alojamiento del artista que no se presenta a escena), o las pérdidas que evitó gracias al incumplimiento (v.gr. en el supuesto de incumplimiento de un negocio que hubiera ocasionado pérdidas a la parte perjudicada)". UNIDROIT, InSTITUTO InTERnaCional PARA La Unificación del Derecho Privado (n. 2), p. 243.

134 "La indemnización cubre las pérdidas que la parte perjudicada haya sufrido y la ganancia que hubiera dejado de obtener"; pérdida o lucro cesante que puede ser presente o futuro según lo expresado. 
generalizada para el perjuicio futuro ${ }^{135}$; y que el artículo 7.4 .3 (1) (Certeza del daño) de los Principios UNIDROIT, comprende en la indemnización, incluso, "la pérdida de una oportunidad o de una chance"136. Según el precepto, el daño futuro es indemnizable cuando sea posible establecerlo con un grado razonable de certeza y añade que la reparación puede tener por objetivo la pérdida de expectativa en proporción a la probabilidad de que acontezca.

La Propuesta, a diferencia de los Principios de UNIDROIT y los PECL, no se pronuncia sobre la procedencia de la indemnización del daño moral por incumplimiento contractual. Probablemente, frente al debate doctrinal sobre el punto en el Derecho Civil español, sería ésta la ocasión de zanjar la cuestión. No veo que sea una buena técnica dejar abierta la interrogante. Éste es el instante en el que debe tomarse partido, sea para excluirlo o fijar reglas que determinen su procedencia. El artículo 7.4.2. (2) dispone que el daño -que puede comprender la indemnización- puede ser pecuniario e incluye, por ejemplo, el sufrimiento físico y la angustia emocional; y el artículo 9: 501 (2), letra (a) declara que la indemnización puede comprender la pérdida no pecuniaria ${ }^{137}$.

El artículo 1208 establece la regla para medir la extensión de la indemnización de daños, distinguiendo según si el incumplimiento fue doloso o 292 no. Si fue doloso, el límite viene dado por la causalidad jurídica, superando la crítica que en su momento formulara a la regla Fernando Pantaleón Prieto, advirtiendo la necesidad de precisar que al deudor, aunque hubiere

135 "The loss for which damages are recoverable includes: (b) future loss which is reasonably likely to occur".

${ }^{136}$ En los comentarios al artículo se lee: "El parágrafo (2) incluye además la pérdida de una expectativa o 'chance', obviamente sólo en proporción a la probabilidad de su ocurrencia. Por lo tanto, el propietario de un caballo que llega demasiado tarde para correr una competición como consecuencia del retraso en su transporte, no puede reclamar una compensación equivalente al primer premio, aun cuando el caballo sea el favorito". UNIDROIT, INSTITUTO Internacional para la Unificación del Derecho Privado (n. 2), p. 245.

${ }^{137}$ En los comentarios del precepto se expresa: "Recoverable loss is not confined to pecuniary loss but may cover, for example, pain and suffering, inconvenience and mental distress resulting from te failure to perform". Y se ofrece la siguiente ilustración (Illustration 7) "A contrata un paquete de vacaciones con $\mathrm{B}$, una empresa que organiza viajes. El paquete incluye una semana en la que se describen espaciosas instalaciones en un hotel de lujo con una excelente cocina. En el hecho, la habitación es pequeña y sucia y la comida es espantosa. A tiene derecho a la indemnización por los inconvenientes y por la pérdida de goce y disfrute que ha experimentado a causa del incumplimiento", The Commission on European Contract Law, Lando, Beale (eds.), "Comment Article" 9:501 PECL (n. 3), p. 436. En los comentarios al artículo 7.4.2 (2) se expresa que el precepto "dispone expresamente la reparación de daños no pecuniarios. Puede tratarse de dolor físico y sufrimiento emocional, la pérdida de ciertos placeres, el daño estético, etc., así como el daño ocasionado por ataques al honor o la reputación”. 
incumplido con dolo, no se le podía hacer responsable de todos los daños que fueran consecuencia del incumplimiento, sino que sólo de aquéllos que le fueran objetivamente imputables. En cambio, para la generalidad de los incumplimientos, la indemnización queda restringida a aquellos daños que se hubiesen previsto o podido prever razonablemente como consecuencia probable del incumplimiento en el momento de la celebración del contrato. Aquí el criterio de imputación objetiva es el fin de protección de la norma, esto es, del contrato. El artículo 1208 coincide, salvo en lo concerniente a la depuración del nexo causal para los incumplimientos dolosos, con el artículo 9:503, que limita la responsabilidad del deudor a los daños que previó o que podría razonablemente haber previsto como probable resultado de su incumplimiento al momento de la conclusión del contrato, a menos que la inejecución fuere dolosa o en forma grosera culpable ${ }^{138}$. Ni la Convención de Viena, en su artículo 74, segunda parte ${ }^{139}$, ni los Principios de UNIDROIT, en su artículo 7.4.4, distinguen según el incumplimiento fue o no doloso, siendo, en todo caso, aplicable el límite de la razonable previsibilidad del daño ${ }^{140}$.

Seguidamente, el artículo 1211 recoge el principio de la mitigación de las pérdidas, excluyendo de la responsabilidad del deudor el daño que el acreedor hubiera podido evitar o reducir, adoptando para ello medidas requeridas por la buena fe, pero imponiéndole la obligación de resarcir los gastos razonablemente ocasionados al acreedor con tal fin, aunque las medidas hayan sido infructuosas. Al igual que los Principios de UNIDROIT y los PECL y a diferencia de la Convención de Viena, la Propuesta no impone al acreedor la carga de mitigar las pérdidas, ni tampoco condiciona la reducción de la indemnización a la alegación que hiciere el deudor en el juicio de incumplimiento, sino que establece como regla delimitadora de

${ }^{138}$ En los comentarios a la segunda parte de la disposición se expresa: "en la última parte del artículo se establece una regla especial en casos de incumplimientos intencionales o groseramente negligentes. En estos casos la indemnización por la que el deudor incumplidor responde no está limitada por la regla de la previsibilidad y el deudor debe compensar la totalidad de los daños, aunque sean imprevisibles al tiempo del contrato", The Commission on European ConTract Law, Lando, Beale (eds.), "Comment Article” 9:503 PECL (n. 3), p. 442.

${ }^{139}$ En contra, para la Convención de Viena, Dietrich Maskow y Fritz Enderlein sostienen que, a pesar de no existir norma expresa, el límite del artículo 74 no sería aplicable cuando el deudor ha incumplido con dolo o fraude. Y para sostenerlo, recurren a los principios en que se apoya la Convención de Viena. Dietrich Maskow, Fritz Enderlein, International Sales Law, United Nations Convention on Contracts Sale of Goods, New York, Oceana Publications, 1992, par. 9.

${ }^{140}$ En los comentarios al artículo 7.4.4 de los Principios de UNIDROIT, se expresa que esta limitación se refiere a la naturaleza misma del contrato: no todos los perjuicios que sufra la parte agraviada se relacionan de modo directo con el contrato. La parte incumplidora -agrega- no debe cargar con la reparación de daños que no pudo prever al momento de celebrar el contrato, ni con los riesgos que, por esa razón, no pudo contemplar cubrir con un seguro. UNIDROIT, Instituto Internacional para la Unificación del Derecho Privado (n. 2), p. 246. 
la causalidad y, por consiguiente, de la indemnización, que el deudor no responderá de los daños que el acreedor hubiere podido evitar o mitigar mediante la adopción de medidas razonables, atendidas las circunstancias. La Propuesta ordena la inclusión de los gastos prudentes en que hubiere incurrido el acreedor, añadiendo, a diferencia de las normas que le sirvieron de modelo, que tal inclusión también tiene lugar cuando las medidas hubieren sido infructuosas.

En efecto, el artículo 7.4.8 de los Principios de UNIDROIT (atenuación del daño) dispone que quien incumple no es responsable del daño sufrido por la parte perjudicada, en tanto el detrimento pudo haber sido reducido si ella hubiera adoptado medidas razonables; y agrega que el acreedor tiene derecho a recuperar cualquier gasto razonablemente efectuado en el intento de reducir el daño.

Si bien el precepto no explicita que la indemnización de los gastos se producirá, incluso, cuando las medidas no tengan éxito, sí se infiere de la expresión "en el intento de reducir el daño". El artículo 9:505 de los PECL (Reduction of Loss) reitera en los mismos términos la regla. En cambio, el artículo 77 de la Convención de Viena prescribe:

"la parte que invoque el incumplimiento del contrato deberá adoptar las medidas que sean razonables atendidas las circunstancias, para reducir la pérdida, incluido el lucro cesante, resultante del incumplimiento. Si no adoptan tales medidas, la otra parte podrá pedir que se reduzca la indemnización de los daños y perjuicios en la cuantía en que debía haberse reducido la pérdida”.

Son manifiestas las diferencias entre el artículo 77 y el artículo de la Propuesta y los preceptos de los Principios de UNIDROIT y los PECL; la Convención de Viena impone una carga al acreedor, se reconoce al deudor el derecho a pedir la reducción, quedando pendiente la interrogante sobre si el juez puede realizarla directamente aplicando el criterio de la causalidad, y se omite disponer sobre los gastos en que incurra el acreedor en la adopción de las medidas y la suerte de los mismos para el caso que las medidas sean infructuosas. La doctrina y la jurisprudencia que aplican la Convención de Viena entienden que la norma del artículo 77 adolecería de un vacío que debe integrarse recurriendo a los Principios de UNIDROIT, en particular al artículo 7.4.8, en tanto principio en que se apoya la Convención según su artículo $7^{141}$.

${ }^{141}$ Para un estudio de la carga de mitigar las pérdidas en la Convención de Viena y su relación con los Principios de UNIDROIT y los PECL, véase VIDAL Olivares, La protección del comprador... (n. 6), pp. 151-175. 
Finalmente, el artículo 1209 de la Propuesta, en lo referente a la causa de exoneración de responsabilidad, sigue el modelo de atribución y exoneración de la Convención de Viena (artículo 79) ${ }^{142}$, los Principios de UNIDROIT (artículo 7.1.7) y los PECL (artículo 8:108), que coinciden en que, por regla general, el deudor queda obligado a la indemnización de daños, salvo que acredite que el incumplimiento se debió a un impedimento u obstáculo ajeno a su esfera de control, que razonablemente no era previsible al momento de contratar y que no pudo evitar, ni superar, en sí, ni en sus consecuencias. El deudor responde porque para él era viable controlar el riesgo del incumplimiento. Es posible dibujar dos áreas de atribución de responsabilidad y una causa única de exoneración. En la primera, hay una esfera de control del deudor en que éste responde sin posibilidad de eximirse; y en la segunda, cabe la exención siempre que el incumplimiento tenga su causa en un impedimento que reúna las condiciones mencionadas. He aquí la causa de exoneración. El sistema de responsabilidad de la Propuesta, siguiendo a los ordenamientos relevantes, si bien prescinde de la diligencia y, por consiguiente, de la culpa, sigue siendo subjetivo al hacer necesaria, para decidir si el deudor está o no exonerado, la valoración de su conducta, la que se confrontará con un arquetipo, ahora el de la persona razonable que, por definición, actúa de buena $\mathrm{fe}^{143}$.

Siguiendo marcadamente el modelo de la Convención de Viena, la exoneración, fuera de tener, por regla general, una eficacia temporal, sólo incide en la indemnización de daños, dejándole a salvo al acreedor el ejercicio de los restantes remedios ${ }^{144}$. No obstante, la disposición de la Propuesta debe interpretarse igual que el artículo 79 (5) de la Convención de Viena, en el sentido de que, por regla general, el acreedor podrá ejercitar cualquiera de los remedios, incluso, la pretensión de cumplimiento, salvo casos de excepción. Por ejemplo, si se trata de una cosa específica y

${ }^{142}$ Para un estudio del artículo 79 de la Convención de Viena como regla de atribución de responsabilidad y de exoneración, véase Álvaro VIDAL OlIVAREs, "Atribución y Exoneración de responsabilidad en la compraventa internacional. Construcción de las reglas a partir del artículo 79 de la Convención de Viena”, en Carlos Pizarro Wilson y Álvaro Vidal OlIVARES, Incumplimiento contractual, resolución e indemnización de daños, Bogotá, Universidad del Rosario, 2010, pp. 313-352.

${ }^{143}$ Véase Vidal Olivares (n. 53).

${ }^{144}$ La propuesta adopta la regla del artículo 79 (5) de la Convención de Viena y se aleja de los Principios de UNIDROIT y los PECL, en tanto extienden el efecto de la causa de exoneración no sólo a la indemnización, sino también a la pretensión de cumplimiento específico. Para un análisis del alcance de la norma de la Propuesta y su contraste con los Principios de UNIDROIT y los PECL, véase FENOY PICón (n. 8), pp. 81-91. La autora expresa: "En la Exposición de Motivos de la Propuesta civil, está claro que al cumplimiento no se le aplica el artículo 1209.I PC. Se trata de una opción de la Sección Civil de la Comisión General de Codificación”. 
el impedimento incide en la exigibilidad de la obligación, el acreedor no podrá demandar la entrega invocando el precepto, sino sólo una vez que cesen los efectos del obstáculo; a diferencia del caso de entrega no conforme de una cosa fungible, dado que el acreedor perfectamente podrá reclamar la sustitución o la reparación de la misma, siempre y cuando concurran sus condiciones de procedencia (artículo 46 de la Convención de Viena). Tampoco cabría el ejercicio de la pretensión de cumplimiento en casos de imposibilidad sobrevenida definitiva de la prestación, atendido que la obligación se extinguiría $^{145}$.

\section{Conclusiones}

1.- La Propuesta española de Modernización del Código Civilrepresenta la consecución de una etapa en el proceso de modernización del Derecho de Obligaciones y del incumplimiento contractual en ese ordenamiento, quedando pendiente el debate académico sobre su contenido y alcance, hasta alcanzar un cuerpo consensuado y que cuente con el apoyo de la civilística española.

2.- Se ha podido constatar que la Comisión de Codificación ha hecho un importante esfuerzo en la elaboración de la Propuesta, en tanto en ella, si bien se sigue el modelo de los ordenamientos que forman el denominado "nuevo derecho de la contratación", se recoge la interpretación correctora, tanto doctrinal como jurisprudencial que se viene realizando desde la década de los noventa. Sería injusto calificar a la Propuesta como una mera importación de los citados ordenamientos.

3.- En lo que concierne al incumplimiento contractual, se asume una concepción amplia y que prescinde de la imputación subjetiva del deudor, salvo para la indemnización de daños. El incumplimiento constituye un elemento articulador de una serie de remedios entre los que el acreedor puede optar con cierta libertad.

4.- Los remedios tienen por objetivo que el acreedor, pese al incumplimiento, obtenga la satisfacción de su interés afectado, ya sea en naturaleza, por el cumplimiento específico o la resolución, o en equivalencia, por medio de la reducción del precio o la indemnización de daños.

5.- Si bien el sistema aparece como funcional al interés del acreedor, no deja de lado la protección del interés del deudor, desde que se encuentran una serie de manifestaciones que permiten afirmar que el

${ }^{145}$ Cfr. Pablo Salvador Coderch, “Artículo 79”, en Díez-Picazo (n. 62), pp. 653-654. 
acreedor, a pesar del incumplimiento, debe conducirse conforme las exigencias de la buena fe; de no hacerlo, el régimen prevé consecuencias negativas a su interés. Se le impone una razonable gestión de los efectos del incumplimiento y entre sus manifestaciones se encuentran la procedencia de la pretensión de cumplimiento específico, el plazo para resolver el contrato, la carga de mitigar las pérdidas, etcétera.

6.- El régimen del incumplimiento de la Propuesta de modernización constituye un verdadero aporte para el debate de nuestra doctrina sobre la pretensión de modernización del Derecho de Obligaciones y Contratos, desde que en España se quiere modificar sustancialmente el Código Civil en esta materia, pero sin romper su tradición y estructura. Tampoco se trata de provocar la reforma de nuestro Código Civil; hace falta un camino por recorrer, por ahora, ésa es mi idea. Y la Propuesta ha de servir de insumo para avanzar hacia la deseada, por algunos, modernización de nuestro Derecho, en particular, del incumplimiento contractual.

\section{BibLIOGRAFÍA}

AlCAlde Silva, Jaime, "La causa de la relación obligatoria", en Alejandro Guzmán Brito (ed.), Estudios de Derecho civil III, Santiago, Legal Publishing, 2008.

Barros Bourie, Enrique, "La diferencia entre 'estar obligado' y 'ser responsable' en el derecho de los contratos", en Hernán Corral, María Sara Rodríguez (eds.), Estudios de Derecho Civil II, Santiago, Lexis Nexis, 2006.

Barros Bourie, Enrique, "Finalidad y alcances de las acciones y los remedios contractuales”, en Alejandro Guzmán Brito (ed.), Estudios de Derecho Civil III, Santiago, Legal Publishing, 2008.

Boneld, Michael Joaquim, I Principi Unidroit nella practica. Casistica e bibliografia riguardanti $i$ principi unidroit dei contratti commerciali internazionali, Milano, Giuffrè, 2002.

Brantt Zumarán, María Graciela, El caso fortuito y su incidencia en el derecho de la responsabilidad civil contractual. Concepto y función del caso fortuito en el Código Civil chileno, Santiago, Legal Publishing, 2010.

Brantt Zumarán, María Graciela, "Exoneración de responsabilidad y extinción de la obligación: delimitación de las nociones de caso fortuito e imposibilidad sobrevenida de la prestación”, en Alejandro GuZMán Brito (ed.), Estudios de Derecho Civil III, Santiago, Legal Publishing, 2008.

Cabanillas Sanchéz Antonio, "El Anteproyecto francés de reforma del Derecho de obligaciones y del Derecho de la prescripción (Estudio preliminar y traducción)", en Anuario de Derecho Civil, fascículo II, Madrid, 2007.

Castro y Bravo, Federico de, El negocio jurídico, 1985, reimpreso en Madrid, Instituto Nacional de Estudios Jurídicos, 2002. 
Catala, Pierre, Avant-projet de réforme du droit des obligations et de la prescription. La documentation française, Paris, Ministère de la Justicie, 2006.

De la Maza Gazmuri, Iñigo, "A propósito del artículo 1861 del Código Civil”, en Departamento de Derecho Privado de la Universidad de Concepción (coord.), Estudios de Derecho Civil v, Santiago, Legal Publishing, 2010.

Díez-PicAzo, Luis, Fundamentos de Derecho Civil Patrimonial II. Las relaciones obligatorias, $6^{\mathrm{a}}$ ed., Navarra, Aranzadi Civitas, 2008.

Díez Picazo, Luis, "La propuesta de modernización del derecho de las obligaciones y contratos", en Boletín del Ministerio de Justicia, año LXV, No 2130, Madrid, abril, 2011.

Diez-Picazo, Luis, "Prólogo", en Antonio Manuel Morales Moreno, La modernización del derecho de las obligaciones, Madrid, Civitas, 2006.

Diez-Picazo, Luis, "Reforma de los Códigos y derecho europeo", en Anuario de Derecho Civil, fascículo IV, volumen LVI, Madrid, 2003.

Díez-Picazo Giménez, Gema, La mora y la responsabilidad contractual, Madrid, Civitas, 1996.

DíEz-PicAzo y Ponce De LeÓn, Luis, "El concepto de causa en el negocio jurídico”, en Anuario de Derecho Civil, fascículo 1, volumen 16, Madrid, 1963.

Díez-Picazo y Ponce de León, Luis, "Prólogo", en Vicente EsPert Sanz, La frustración del fin del contrato, Madrid, Tecnos, 1968.

Díez-Picazo, Luis, Encarna Roca Trias y Antonio Manuel Morales Moreno, Los Principios del Derecho Europeo de Contratos, Madrid, Civitas, 2002.

EBers, Martín, "La nueva regulación del incumplimiento contractual en el BGB, tras la Ley de modernización del Derecho de obligaciones de 2002", en Anuario de Derecho Civil, fascículo IV, volumen LVI, Madrid, 2003.

Fenoy Picón, Nieves, El sistema de protección del comprador, Madrid, Tirant lo Blanch, 2006.

Fenoy Picón, Nieves, "La entidad del incumplimiento en la resolución del contrato: análisis comparativo del artículo $1124 \mathrm{CC}$ y del artículo 121 del Texto Refundido de Consumidores", en Anuario de Derecho Civil, fascículo 1, tomo LXII, Madrid, 2009.

Fenoy Picón, Nieves, "La modernización del régimen del incumplimiento del contrato: Propuestas de la Comisión General de Codificación. Parte Primera: Aspectos generales. El incumplimiento", en Anuario de Derecho Civil, fascículo I, tomo LXIII, Madrid, 2010.

Fenoy Picón, Nieves, La falta de conformidad e incumplimiento en la compraventa (Evolución del ordenamiento español), Madrid, Centro de Estudios Registrales, 1996.

Fenoy Picón, Nieves, "Sentencia de 10 de julio de 2003", en Cuadernos Civitas de jurisprudencia civil, $\mathrm{N}^{\circ}$ 68, Navarra, 2005.

Instituto de Investigaciones Jurídicas Centro Mexicano, Comentario al artículo 7.1.1 Principios de Unidroit sobre contratos comerciales internacionales 2004, en www. 
bibliojuridica.org/libros/libro.htm?l=2488, p. 200, visitado el 29 de diciembre de 2010.

Jerez Delgado, Carmen y Máximo Juan Pérez García, "La Comisión General de Codificación y su labor en la Modernización del Derecho de Obligaciones", en RJUAM, $\mathrm{N}^{\circ} 19$, Madrid.

LÓPEZ LÓPEZ, Ángel, "Artículo 48-50", en Luis Díez-PiCAzo (director), La compraventa internacional de mercaderías. Comentarios a la Convención de Viena, Navarra, Civitas, 1998.

Maskow, Dietrich, Fritz Enderlein, International Sales Law, United Nations Convention on Contracts Sale of Goods, New York, Oceana Publications, 1992.

Mazeaud, Denis, "La reformé du droit français des contrats: trois projets en concurrence", dans Sarah Bros et Blandine MALlet-Bricout, Liber Amicorum Christian Larroumet, Paris, Économica, 2009.

Mejías Alonzo, Claudia, "El incumplimiento contractual y sus modalidades" en Alejandro GuZmán Brito (ed.), Estudios de Derecho Civil III, Santiago, Legal Publishing, 2008.

Messineo, Francesco, Il contratto II. Diritto privato, teoria generale, Milano, Giuffrè editore, 1968.

Ministerio de Justicia, “Exposición de motivos”, en Propuesta por la modernización del Derecho de Obligaciones y Contratos, Madrid, Ministerio de Justicia, 2009.

Ministerio DE Justicia, "Exposición de motivos de la Propuesta de modificación del Código Civil en materia de compraventa", en Boletín de Información, Madrid, Ministerio de Justicia, 2005.

Ministerio de Justicia, "Propuesta de Anteproyecto de Ley de Modificación del Código de Comercio, Parte General sobre Contratos mercantiles y sobre prescripción y caducidad", en Boletín de Información, año LXI, N 2006, Madrid, febrero de 2006.

Morales Moreno, Antonio Manuel, "El derecho a la reparación o sustitución de la cosa no conforme y la naturaleza de la obligación del vendedor", en Antonio Manuel Morales Moreno, La modernización del derecho de obligaciones, Navarra, Civitas, 2006.

Morales Moreno, Antonio Manuel, "El 'propósito práctico' y la idea de negocio jurídico en Federico de Castro", en Antonio Manuel Morales Moreno, Modernización del Derecho de obligaciones, Madrid, Civitas, 2006. Antes publicado en Anuario de Derecho Civil, fascículo Iv, volumen 36, Madrid, 1983.

Morales Moreno, Antonio Manuel, "Evolución del concepto de obligación en Derecho español", en Antonio Manuel Morales Moreno, La Modernización del Derecho de Obligaciones, Navarra, Thomson-Civitas, Cizur Menor, 2006.

Morales Moreno, Antonio Manuel, Incumplimiento del contrato y lucro cesante, Navarra, Thomson Civitas, 2010.

Morales Moreno, Antonio Manuel, "La pretensión de cumplimiento y pretensión indemnizatoria", en Antonio Manuel Morales Moreno, La modernización del derecho de obligaciones, Navarra, Civitas, 2006. 
Muller-Chen, Markus, "Article 50", in Peter Schlechtriem and Ingeborg SchwenZER (eds.), Commentary on the UN Convention on the International Sale of Goods (CISG), Second (English) Edition, Oxford, University Press, New York, 2005.

Neumann, Thomas, "Shared Responsibility under Article 80 CISG", in Nordic Journal Commercial Law, $\mathrm{N}^{\circ}$ 2, 2009, disponible en internet en http://www.njcl. fi/2_2009/neumann_thomas.pdf, sitio Web visitado el 3 de marzo de 2011.

Paes de Barros Leães, Luis, "Notas sobre la inexecução", en Michael Joachim Bonell, Principi per $i$ contratti commerciali internazionali e il sistema giuridico latinoamericano, Padova, Cedam, 1996.

Pantaleón Prieto, Fernando, "El sistema de responsabilidad contractual (materiales para un debate)", en Anuario de Derecho Civil, fascículo III, volumen 44, Madrid, 1991.

Pantaleón Prieto, Fernando, "Las nuevas bases de la responsabilidad contractual", en Anuario de Derecho Civil, fascículo IV, volumen 46, Madrid, 1993.

Pantaleón Prieto, Fernando, "El sistema de responsabilidad contractual (Materiales para un debate)", en Anuario de Derecho Civil, fascículo 3, tomo XuIv, Madrid, 1991.

Pizarro Wilson, Carlos, "Hacia un sistema de remedios al incumplimiento contractual", en Alejandro GuZmán Brito (ed.), Estudios de Derecho Civil III, Santiago, Legal Publishing, 2008.

300 Pizarro Wilson, Carlos, "La culpa como elemento constitutivo del incumplimiento en las obligaciones de medio o de diligencia", en Revista de Derecho PUCV, vol. Xxxi, $\mathrm{N}^{\circ} 1$, Valparaíso, 2008.

Pizarro Wilson, Carlos, "Las cláusulas resolutorias en el Derecho civil chileno", en Cuadernos de Análisis Jurídico, Santiago, Ediciones de la Universidad Diego Portales, Colección de Derecho Privado, 2006, vol. III.

Pizarro Wilson, Carlos, "Una mirada a los remedios al incumplimiento contractual en los proyectos de reforma en Francia", en Revista de Derecho PUCV, vol. ?, $\mathrm{N}^{\mathrm{O}}$ 1, 2011 (en prensa).

Salvador Coderch, Pablo, "Alteración de circunstancias en el art. 1213 de la Propuesta de Modernización del Código Civil en materia de Obligaciones y Contratos", en Indret, $\mathrm{N}^{\mathrm{O}} 2$ 2, 2009, disponible en http://www.indret.com/ pdf/687_es.pdf, visitado el 14 de febrero de 2011.

Salvador Coderch, Pablo, "Comentario al artículo 80 de la Convención de Viena", en Luis DíEz-PicAzo (director y coordinador), La compraventa internacional de mercaderías. Comentario de la Convención de Viena, Navarra, Civitas, 1998.

San Miguel Pradera, Lis Paula, La resolución del contrato por incumplimiento y sus modalidades de ejercicio, Madrid, Colegio de Registradores de la Propiedad y Mercantiles de España, 2004.

San Miguel Pradera, Lis Paula, "La modernización del Derecho de obligaciones y la resolución por incumplimiento en los ordenamientos español y chileno", Iñigo DE la MAZA Gazmuri (coord.), "Modernización del derecho de las obliga- 
ciones", en Cuadernos de AnálisisJurídico, Santiago, Ediciones de la Universidad Diego Portales, Colección Derecho Privado vol. vi (en prensa).

Schlechtriem, Peter, "Uniform Sales Law. The UN-Convention on Contracts for the International Sales of Goods", in Law and Economics International Trade, $\mathrm{N}^{\circ}$ 9, Viena, 1989.

Sivesand, Hanna, The Buyer's Remedies for Non-Conforming Goods. Should there Free Choice or are Restrictions Necessary?, Munchen, Armand Colin Editeur, 2005.

Stoll Hans, Georg Gruber, "Article 79. Commentary on the UN Convention on the International Sale of Goods (CISG)", in Peter Schlechtriem and Ingeborg Schwenzer (eds.), Second (English) Edition, Oxford, University Press, New York, 2005.

Study Group on a European Civil Code and Research Group on EC Private Law (AcQuis Group), edited by Christian von Bar, Eric Clive and Hans Schulte -Nölke and Hugh Beale, Johnny Herre, Jérome Huet, Peter Schlechtriem, Matthias Storme, Stephen Swann, Paul Varul, Anna Veneziano and Fryderyk Zoll, Principles, Definitions and Model Rules of European Private Law, Draft Common Reference (DCFR) Interim Outiline, Munich, European Law Publishers, 2008.

Study Group on a European Civil Code, Sales (PELS), prepared by Hondius, Ewoud, Heutger, Viola, Jeloschek, Christoph, Sivesand, Hanna, WiewioRowsKa, Aneta, Principles of European Law on Sales, Munich, European Law Publishers, 2008.

The Commission on European Contract Law, Ole Lando, Hugh Beale (eds.), Principles of European Contract Law, The Hague, Kluwer Law International, 2000.

UNIDROIT, Instituto Internacional para la Unificación del Derecho PriVADO, Principios UNIDROIT sobre los contratos comerciales internacionales, Roma, Ediciones UNIDROIT, 2004. Versión española dirigida por Alejandro A.M. Garro, Madrid, Ediciones UNIDROIT, 2007.

VANTo, Jarno, Commentary on the manner in which the Principles of European Contract Law may be used to interpret or sumplement Article 50 of the CISG, disponible en internet en http://cisgw3.law.pace/cisg/text/anno-art-50.html, visitado el 14 de febrero de 2011.

Vidal Olivares, Álvaro, "Atribución y Exoneración de responsabilidad en la compraventa internacional. Construcción de las reglas a partir del artículo 79 de la Convención de Viena", en Carlos Pizarro Wilson y Álvaro Vidal OlIVAREs, Incumplimiento contractual, resolución e indemnización de daños, Bogotá, Universidad del Rosario, 2010.

Vidal Olivares, Álvaro, "Cumplimiento e Incumplimiento Contractual en el Código Civil. Una perspectiva más realista", en Revista Chilena de Derecho, volumen 34, N 1, Santiago, 2007.

Vidal Olivares, Álvaro, "El cambio de paradigma en el incumplimiento contractual”, en Patricio Carvajal Ramírez (coord.), Estudios en Homenaje el Profesor Alejandro Guzmán Brito, (en prensa). 
Vidal Olivares, Álvaro, "El incumplimiento de las obligaciones con objeto fungible y los remedios del acreedor afectado. Una relectura de las disposiciones del Código Civil sobre incumplimiento", en Alejandro GuzMán Brito (ed.), El Código Civil de Chile (1855-2005), Santiago, LexisNexis 2007.

Vidal Olivares, Álvaro, "La construcción de la regla contractual en el derecho civil de los contratos", en RPUCV, vol. xxi, Valparaíso, 2000.

Vidal Olivares, Álvaro, "La gestión razonable de los efectos del incumplimiento en la compraventa internacional", en Revista de Derecho de la Universidad Austral de Chile, vol. 18, $\mathrm{N}^{\circ}$ 1, Valdivia, 2005.

Vidal Olivares, Álvaro, "La noción de incumplimiento esencial en el Código Civil", en Revista de Derecho PUCV, vol. xxxiI, No $1^{\circ}$, Valparaíso, 2009.

Vidal Olivares, Álvaro, "La noción de persona razonable en la compraventa internacional”, en Antonio Cabanillas SÁnchez (ed.), EstudiosJurídicos en Homenaje al profesor Diez Picazo y Ponce de León, Madrid, Civitas, 2003, tomo II.

Vidal Olivares, Álvaro, "La pretensión de cumplimiento específico y su inserción en el sistema de remedios por incumplimiento en el Código Civil", en Hernán Corral, María Sara Rodríguez (eds.), Estudios de Derecho Civil II, Santiago, Lexis Nexis, 2006.

Vidal Olivares, Álvaro, La protección del comprador: régimen de la Convención de Viena y su contraste con el Código Civil, Valparaíso, Ediciones Universitarias de Valparaíso, 2006.

Vidal Olivares, Álvaro, "La responsabilidad del deudor por incumplimiento de su tercero encargado en la compraventa internacional de mercaderías", en Cuadernos de Análisis Jurídico, Santiago, Ediciones de la Universidad Diego Portales, Colección de Derecho Privado, 2006 vol. III.

Will, Michael, "Article 50", in Cesare Massimo BiAnCA y Michael Joachim Bonell, Commentary on the International Sales Law, The Vienna Sales Convention, Milan, Giuffrè, 1987.

Zimmermann, Reinhard, El nuevo Derecho alemán de obligaciones. Un análisis desde la historia y el Derecho Comparado, traducción de Esther Arroyo i Amayuelas, Barcelona, Bosch, 2008. 